\title{
Concise, Asymmetric, Stereocontrolled Total Synthesis of Stephacidins A, B and Notoamide B
}

\author{
Gerald D. Artman III, Alan W. Grubbs and Robert M. Williams* \\ Department of Chemistry, Colorado State University, Fort Collins, 80523 \\ University of Colorado Cancer Center, Aurora, CO 80045
}

rmw@lamar.colostate.edu

\section{Supporting Information}

GENERAL METHODS: All reactions were performed in single-neck round bottom flasks fitted with rubber septa under positive pressure of argon, unless otherwise noted. Organic solutions were concentrated under reduced pressure by rotary evaporation below $40{ }^{\circ} \mathrm{C}$ at 20 Torr. Analytical and preparative thin-layer chromatography (TLC) was performed using glass plates pre-coated with a 0.25$\mathrm{mm}$ layer of silica gel impregnated with a fluorescent indicator $(254 \mathrm{~nm})$. Reaction progress was followed by TLC analysis and visualized by UV light and/or submersion in standard TLC stains $\left(\mathrm{KMnO}_{4}\right.$, Vanillin, Anisaldehyde, etc.) followed by heating on a hot plate $\left(\sim 200^{\circ} \mathrm{C}, 15 \mathrm{~s}\right)$. Flash silica gel chromatography was conducted as described by Still and coworkers using $60 \AA$, standard grade silica gel purchased from Sorbtech. ${ }^{1} \mathrm{H}$ and ${ }^{13} \mathrm{C}$ NMR spectra were obtained using Varian $300 \mathrm{MHz}, 400 \mathrm{MHz}$ or $500 \mathrm{MHz}$ spectrometers. The chemical shifts are given in parts per million (ppm) relative to TMS at $\delta$ $0.00 \mathrm{ppm}$ or to residual $\mathrm{CDCl}_{3} \delta 7.27 \mathrm{ppm}$ for proton spectra and relative to $\mathrm{CDCl}_{3}$ at $\delta 77.23 \mathrm{ppm}$ for carbon spectra, unless otherwise noted. IR spectra were recorded on a Perkin-Elmer 1600 FTIR as thin films in $\mathrm{CH}_{2} \mathrm{Cl}_{2}$. Mass spectra were obtained using a Fisons VG Autospec spectrometer. Flash column chromatography was performed with silica gel grade 60 (230-400 mesh). All materials were obtained from commercially available sources and used without further purification. Dichloromethane $\left(\mathrm{CH}_{2} \mathrm{Cl}_{2}\right)$, tetrahydrofuran (THF), toluene (PhMe), benzene $(\mathrm{PhH}), N, N$-dimethylforamide (DMF), acetonitrile $\left(\mathrm{CH}_{3} \mathrm{CN}\right)$, triethylamine $\left(\mathrm{Et}_{3} \mathrm{~N}\right), \mathrm{N}, \mathrm{N}$-diisopropylamine and methanol $(\mathrm{MeOH})$ were all purified using a LabContour solvent purification system. Sodium hydride $(\mathrm{NaH})$ was dispersed in petroleum ether, 
stirred for $15 \mathrm{~min}$, filtered through a sintered glass funnel and washed with an additional aliquot of Pet. $\mathrm{Et}_{2} \mathrm{O}$ before use.

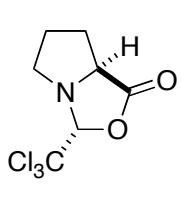

12

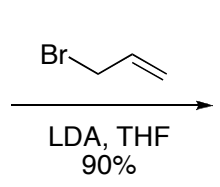

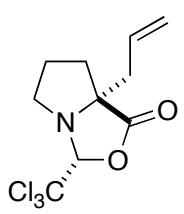

13

$(3 R, 7 \mathrm{a} R)$-7a-allyl-3-(trichloromethyl)tetrahydropyrrolo[1,2-c]oxazol-1(3H)-one (13). To a flamedried $500-\mathrm{mL}$ round-bottomed flask, $N, N$-diisopropylamine $(10 \mathrm{~mL}, 71 \mathrm{mmol})$ is added to tetrahydrofuran (THF, $140 \mathrm{~mL}$ ). The reaction vessel is cooled to $-78^{\circ} \mathrm{C}$ in a $\mathrm{CO}_{2}$ /isopropanol bath before $n$-butyllithium in hexane (Aldrich, $1.6 \mathrm{M}, 46 \mathrm{~mL}, 74 \mathrm{mmol}$ ) is added via syringe. The reaction mixture is stirred for an additional $30 \mathrm{~min}$ at $-78^{\mathrm{O}} \mathrm{C}$ under argon. In a separate $250-\mathrm{mL}$ round-bottomed flask, commercially available $(3 R, 7 a S)$-3-(trichloromethyl)tetrahydropyrrolo[1,2-c]oxazol-1(3H)-one (12, AK Scientific, $12.2 \mathrm{~g}, 49.9 \mathrm{mmol})$ is dissolved in THF (100 mL). This solution is cooled to $0^{\circ} \mathrm{C}$ and stirred for $10 \mathrm{~min}$. A cannula is used to deliver the ethereal solution to the LDA solution at $-78^{\circ} \mathrm{C}$ under argon over $5 \mathrm{~min}$. The resulting solution is stirred for an additional $20 \mathrm{~min}$ at $-78^{\circ} \mathrm{C}$ before the addition of commercially available allyl bromide (Alfa Aesar, $7.8 \mathrm{~mL}, 90 \mathrm{mmol}$ ) via syringe in a single portion. The reaction mixture is slowly allowed to warm to $-40^{\circ} \mathrm{C}$, where it is maintained for an additional $2-3 \mathrm{~h}$. Progress of the alkylation can be monitored by TLC developing plates in 1:7 EtOAc:hexanes (product $\mathrm{R}_{f}=0.56$; starting material $\mathrm{R}_{f}=0.39$ ). The reaction mixture is then poured into a 1 - $\mathrm{L}$ separatory funnel filled with $300 \mathrm{~mL}$ of water. The aqueous solution is extracted with chloroform ( $3 \mathrm{x} 300 \mathrm{~mL})$. The combined organic extracts are dried over $\mathrm{Na}_{2} \mathrm{SO}_{4}$ and concentrated in vacuo to afford the allyl lactone 13 $(10.7 \mathrm{~g}, 75 \%)$ as an orange oil, which is generally used without purification. Analytically pure material for spectral analysis was generated using PTLC (1:7 EtOAc:hexane) to afford $\mathbf{1 3}$ as a light yellow oil, which displayed excellent correlation to the previously reported data. $[\alpha]_{\mathrm{D}}=+34.0\left(c 2, \mathrm{C}_{6} \mathrm{H}_{6}\right)$, lit. ${ }^{1}[\alpha]_{\mathrm{D}}$ $=+33\left(c 2, \mathrm{C}_{6} \mathrm{H}_{6}\right)$.

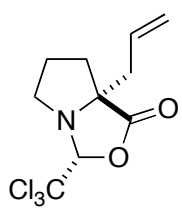

13

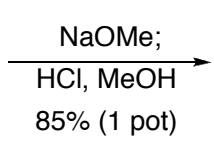

$\mathrm{HCl}, \mathrm{MeOH}$
$85 \%$ (1 pot) 
(R)-methyl 2-allylpyrrolidine-2-carboxylate hydrochloride (11). A 500-mL three-neck roundbottomed flask equipped with a magnetic stirbar, a reflux condenser with an argon inlet is fitted on the center neck, a 125-mL pressure-equalizing additional funnel with rubber septum is fitted on the left neck, and a rubber septum fitted on the right neck of the flask. The rubber septum is removed and the flask is charged with allyl lactone $13(8.19 \mathrm{~g}, 28.8 \mathrm{mmol})$ and $\mathrm{MeOH}(100 \mathrm{~mL})$. Small chunks of $\mathrm{Na}^{0}$ (Aldrich, $400 \mathrm{mg}, 17.4 \mathrm{mmol}$ ) are slowly added over $30 \mathrm{~min}$ by removal of the rubber septum from the right neck of the flask and the reaction mixture is stirred for an additional 30 min once no more of the starting material is observed by TLC (1:5 EtOAc:hexanes). The reaction vessel is cooled in an ice/water bath and the pressure-equalizing addition funnel is charged with commercially available AcCl (Aldrich, $40 \mathrm{~mL}, 563 \mathrm{mmol}$ ), which is added dropwise into the reaction mixture over $1 \mathrm{~h}$. The funnel is removed and replaced with a rubber septum and an argon inlet and the resulting milky brown solution is heated to reflux until no more of the intermediate $N$-formyl ester remains by TLC (1:1 EtOAc:hexanes, $N$-formyl ester $\left.\mathrm{R}_{\mathrm{f}}=0.25 ; 11 \mathrm{R}_{f}=0.00\right)$. The volatile organics are removed under reduced pressure and the resulting oily solid is diluted with $\mathrm{CH}_{2} \mathrm{Cl}_{2}(50 \mathrm{~mL})$. The precipitated $\mathrm{NaCl}$ is removed via filtration through a Büchner funnel. The filtrate is concentrated under reduced pressure and the process of dilution with $\mathrm{CH}_{2} \mathrm{Cl}_{2}$ /filtration is repeated two additional times to afford a brown oil. Purification of the crude hydrochloride salt is achieved using flash silica gel chromatography eluting with a gradient of 95:5 $\rightarrow 90: 10 \mathrm{CH}_{2} \mathrm{Cl}_{2}: \mathrm{MeOH}$ to afford the amine salt $11(5.0 \mathrm{~g}, 85 \%)$ as an oil, which crystallizes upon standing under reduced pressure. Spectral correlation was identical to the previously reported data/. However, we performed our NMR experiments in $\mathrm{CDCl}_{3}$ vs. $\mathrm{D}_{2} \mathrm{O} .{ }^{1}[\alpha]_{\mathrm{D}}=+74.0\left(\right.$ c $\left.2, \mathrm{CH}_{2} \mathrm{Cl}_{2}\right) ;{ }^{1} \mathrm{H}$ NMR $\left(300 \mathrm{MHz}, \mathrm{CDCl}_{3}\right) \delta$ 1.72-2.25 (m, 3H), 2.30-2.50 (m, 1H), 2.71-3.07 (m, 2H), 3.33-3.76 (m, 2H), 3.85 (s, 3H), 5.20-5.33 (m, 2H), 5.72-5.99 (m, 1H), 8.06 (br. s, 1H).

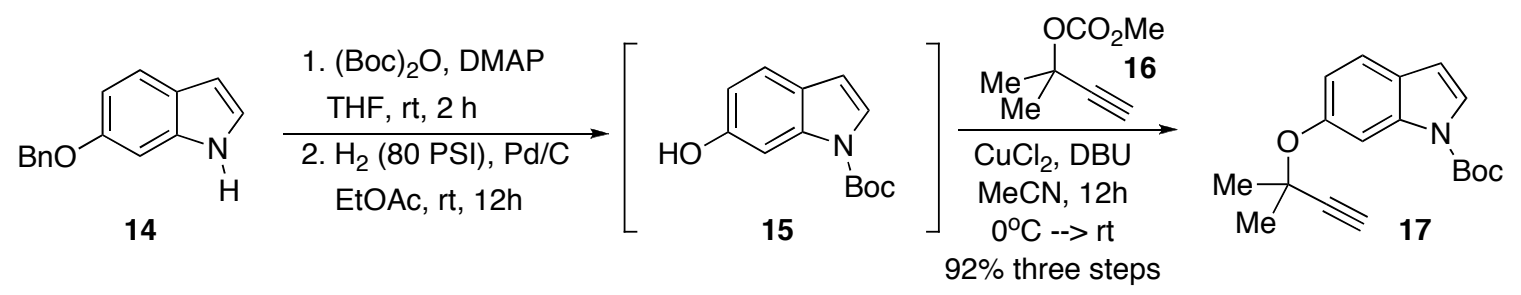

tert-Butyl 6-(2-methylbut-3-yn-2-yloxy)-1H-indole-1-carboxylate (17). To a $500 \mathrm{~mL}$ round bottom flask, commercially available 6-benzyloxyindole (14, 3B Medical Systems, 4.47 g, 20.0 mmol) was dissolved in THF (200 mL). Commercially available (Boc) $)_{2} \mathrm{O}$ (Fluka, $4.74 \mathrm{~g}, 21.7 \mathrm{mmol}$ ) and DMAP (Aldrich, $237 \mathrm{mg}, 1.94 \mathrm{mmol}$ ) are added sequentially to the reaction flask. The reaction mixture was S-3 
stirred until no more starting material remained by TLC (1:9 EtOAc:hexane, product $\mathrm{R}_{f}=0.75 ; \mathbf{1 4} \mathrm{R}_{f}=$ $0.3,2 \mathrm{~h})$. The volatile organics were removed under reduced pressure and the crude oily product is used without further purification.

The crude $N$-Boc indole was diluted with EtOAc $(100 \mathrm{~mL})$ and transferred to a high-pressure hydrogenation vessel. Commercially available $10 \% \mathrm{Pd} / \mathrm{C}(604 \mathrm{mg})$ is added in a single portion and the vessel was sealed. 80 PSI of $\mathrm{H}_{2}$ is introduced and the reaction vessel is evacuated. This process is repeated twice more. The vessel is then placed under 80 PSI of $\mathrm{H}_{2}$ pressure and stirred at rt overnight. TLC analysis of the reaction mixture after $10 \mathrm{~h}$ showed no more starting material remained (1:9 EtOAc:hexane, $15 \mathrm{R}_{f}=0.2$; starting material $\mathrm{R}_{f}=0.75$ ). The remaining $\mathrm{H}_{2}$ gas is evacuated and the palladium catalyst is removed via filtration through a pad of Celite ${ }^{\circledR}$. The filtrate of low boiling organics is removed in vacuo to afford intermediate $\mathbf{1 5}$ as an aoil, which is used without further purification.

The crude phenol 15 was dissolved in $\mathrm{CH}_{3} \mathrm{CN}(40 \mathrm{~mL})$ and cooled to $0^{\circ} \mathrm{C}$. Commercially available $\mathrm{CuCl}_{2} \bullet 2 \mathrm{H}_{2} \mathrm{O}$ (Aldrich, $3.1 \mathrm{mg}, 0.018 \mathrm{mmol}$ ) is then added followed methyl 2-methylbut-3-yn2-yl carbonate $(\mathbf{1 6}, 8.50 \mathrm{~g}, 60.0 \mathrm{mmol})$. The reaction mixture is stirred for $15 \mathrm{~min}$ before the addition of commercially available DBU (Aldrich, $3.3 \mathrm{~mL}, 22.1 \mathrm{mmol}$ ) via syringe. The reaction mixture remains at $0^{\circ} \mathrm{C}$ and was stirred until the starting phenol 15 is consumed by TLC (1:9 EtOAc: hexane, $\left.\sim 3 \mathrm{~h}\right)$. The volatile organics are removed under reduced pressure and the resulting oil is diluted with EtOAc (150 $\mathrm{mL})$. The organic solution is washed sequentially with $1 \mathrm{~N} \mathrm{HCl}(50 \mathrm{~mL})$, water $(50 \mathrm{~mL})$ and brine $(50$ $\mathrm{mL})$. The organic layer is dried over $\mathrm{Na}_{2} \mathrm{SO}_{4}$, filtered and concentrated in vacuo. The resulting brown oil is purified by flash silica gel chromatography (1:10 EtOAc:hexanes) to afford the desired aryl ether 17 (5.51 g, $92 \%$ over three steps) as a colorless oil. IR (Thin Film) 3305, 2984, 2252, 1727, 1534, 1474, 908, $732 \mathrm{~cm}^{-1} ;{ }^{1} \mathrm{H}$ NMR (300 MHz, $\left.\mathrm{CDCl}_{3}\right) \delta 1.09$ (s, 9H), 1.69 (s, 6H), $2.57(\mathrm{~s}, 1 \mathrm{H}), 6.52(\mathrm{dd}, J=3.6$, $0.6 \mathrm{~Hz}, 1 \mathrm{H}), 7.12(\mathrm{dd}, J=8.7,2.4 \mathrm{~Hz}, 1 \mathrm{H}), 7.43(\mathrm{~d}, J=8.7 \mathrm{~Hz}, 1 \mathrm{H}), 7.55$ (d, $J=3.9 \mathrm{~Hz}, 1 \mathrm{H}), 8.01$ (br. s, $1 \mathrm{H}) ;{ }^{13} \mathrm{C} \mathrm{NMR}\left(75 \mathrm{MHz}, \mathrm{CDCl}_{3}\right) \delta 152.99,135.50,126.75,125.86,120.71,118.63,117.56,109.50$, 107.25, 86.51, 83.75, 73.98, 73.25, 29.86, 28.46; HMRS-FAB: $[\mathrm{M}+\mathrm{H}]^{+}$calcd for $\mathrm{C}_{18} \mathrm{H}_{21} \mathrm{NO}_{3}, 300.1594$; found, 300.1601 .
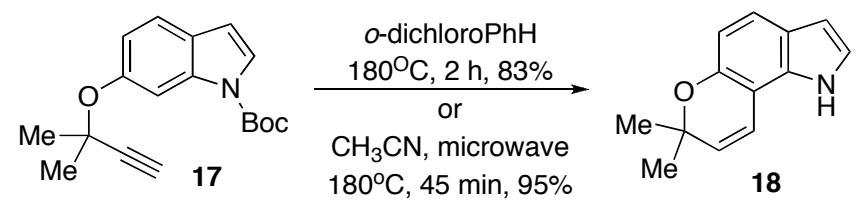
7,7-Dimethyl-1,7-dihydropyrano[2,3-g]indole (18). Using a CEM Discovery Microwave Reactor, the aryl ether $17(5.51 \mathrm{~g}, 18.3 \mathrm{mmol})$ is dissolved in $\mathrm{CH}_{3} \mathrm{CN}(210 \mathrm{~mL})$ in an Erlenmeyer flask. $70-\mathrm{mL}$ aliquots are removed from the flask and placed in a CEM 80-mL reaction vessel containing a stir bar. The reaction vessel is placed in the microwave cavity, sealed and heated at $180^{\circ} \mathrm{C}$ for $20 \mathrm{~min}$ at $300 \mathrm{~W}$ of power. This process is repeated until all of the aryl ether $\mathbf{1 7}$ had been cycled through the microwave (3 runs). The combined reaction mixtures are concentrated under reduced pressure and the resulting brown oil is purified by flash silica gel chromatography (1:9 EtOAc:hexanes) to afford the desired pyranoindole 18 (3.44 g, 95 \%) as a light yellow oil. IR (Thin Film) 3480, 3423, 2978, 1642, 1489, 909, 732, $650 \mathrm{~cm}^{-1} ;{ }^{1} \mathrm{H}$ NMR (300 MHz, $\left.\mathrm{CDCl}_{3}\right) \delta 1.48$ (s, 6H), 5.67 (d, $\left.J=9.8 \mathrm{~Hz}, 1 \mathrm{H}\right), 6.47$ (dd, $J=3.2,3.0$ $\mathrm{Hz}, 1 \mathrm{H}), 6.57$ (d, $J=9.7 \mathrm{~Hz}, 1 \mathrm{H}), 6.69(\mathrm{~d}, J=8.5 \mathrm{~Hz}, 1 \mathrm{H}), 7.06(\mathrm{dd}, J=3.1,3.0 \mathrm{~Hz}, 1 \mathrm{H}), 7.32(\mathrm{~d}, J=8.4$ $\mathrm{Hz}, 1 \mathrm{H}), 8.05$ (br s, $1 \mathrm{H}) ;{ }^{13} \mathrm{C} \mathrm{NMR}\left(75 \mathrm{MHz} \mathrm{CDCl}_{3}\right) \delta 148.88,132.49,129.73,123.15,122.72,121.08$, 117.19, 111.04, 105.18, 103.37, 75.93, 27.76; HRMS-FAB: $[\mathrm{M}+\mathrm{H}]^{+}$calcd for $\mathrm{C}_{13} \mathrm{H}_{13} \mathrm{NO}, 200.1070$; found, 200.1069 .
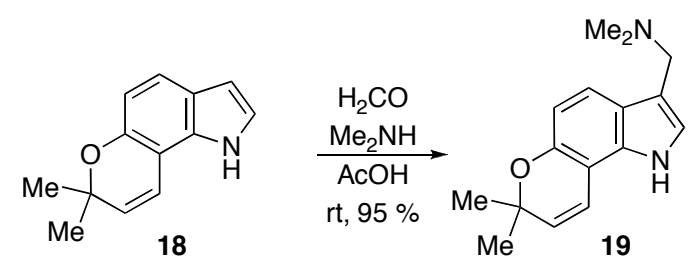

(7,7-Dimethyl-1,7-dihydropyrano[2,3-g]indol3-yl)- $N, N$-dimethylmethanamine (19). To a $100 \mathrm{~mL}$ round bottom flask, aqueous formaldehyde $(37 \%, 0.80 \mathrm{~mL}, 9.86 \mathrm{mmol})$ was diluted with glacial $\mathrm{AcOH}$ (30 mL). Aqueous dimethylamine (40\%, $4.2 \mathrm{~mL}, 37.3 \mathrm{mmol})$ was then added followed by the indole 18 $(1.74 \mathrm{~g}, 8.73 \mathrm{mmol})$. The reaction was stirred at $\mathrm{rt}$ until the disappearance of the starting indole 18 by TLC (1:9 EtOAc:hexane, $\sim 2 \mathrm{~h}$ ). The reaction mixture was then diluted with $2 \mathrm{~N} \mathrm{NaOH}$ to raise the $\mathrm{pH}>$ 10. The aqueous solution was extracted with $\mathrm{Et}_{2} \mathrm{O}(3 \times 100 \mathrm{~mL})$. The combined organic extracts were dried over $\mathrm{Na}_{2} \mathrm{SO}_{4}$ and the volatile organics removed under reduced pressured to afford the desired gramine $19(2.13,95 \%)$ as a golden foam, which was used without further purification. IR (Thin Film) 3478, 2978, 2777, 1641, 1436, 731, $650 \mathrm{~cm}^{-1}$; ${ }^{1} \mathrm{H}$ NMR (300 MHz, $\mathrm{CDCl}_{3}$ ) $\delta 1.45$ (s, 6H), 2.29 (s, 6H), $3.58(\mathrm{~s}, 2 \mathrm{H}), 5.59(\mathrm{~d}, J=13.0 \mathrm{~Hz}, 1 \mathrm{H}), 6.49$ (d, $J=9.7 \mathrm{~Hz}, 1 \mathrm{H}), 6.67$ (d, $J=8.7 \mathrm{~Hz}, 1 \mathrm{H}), 6.92$ (br. s, 1H), 7.42 (d, $J=8.5 \mathrm{~Hz}, 1 \mathrm{H}), 8.49$ (br. s, $1 \mathrm{H}) ;{ }^{13} \mathrm{C} \mathrm{NMR}\left(75 \mathrm{MHz}, \mathrm{CDCl}_{3}\right.$ ) $\delta$ 153.67, 132.97, 129.75, 122.40, 119.71, 117.61, 117.21, 114.25, 110.76, 105.14, 75.89, 54.85, 45.64, 27.66; HRMS-FAB: $[\mathrm{M}+\mathrm{H}]^{+}$calcd for $\mathrm{C}_{16} \mathrm{H}_{20} \mathrm{~N}_{2} \mathrm{O}, 257.1648$; found, 257.1644 . 

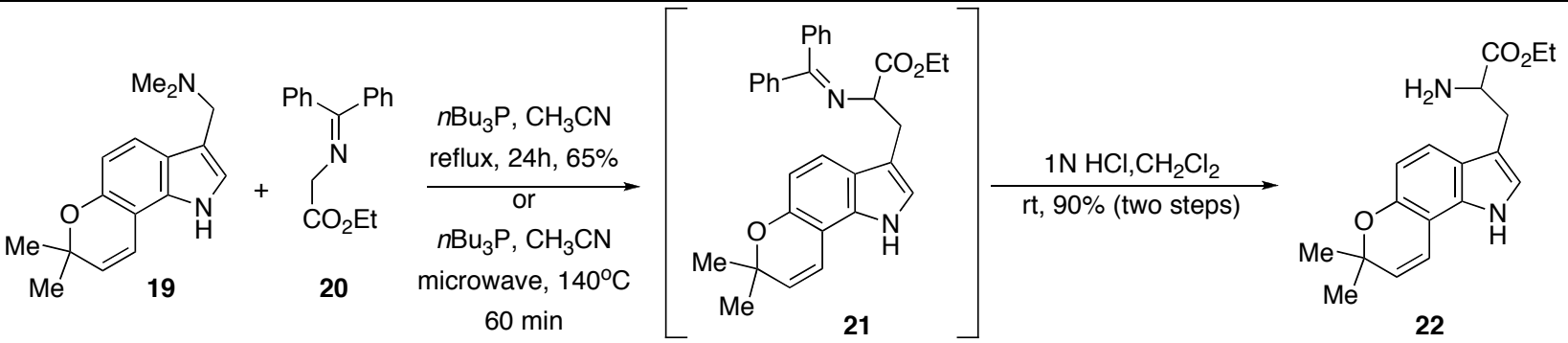

Tryptophan Derivative 22. To a 250-mL Erlenmeyer flask, gramine $19(2.12 \mathrm{~g}, 8.27 \mathrm{mmol})$ is suspended in $\mathrm{CH}_{3} \mathrm{CN}(120 \mathrm{~mL})$. Commercially available glycine 20 (Aldrich, $2.22 \mathrm{~g}, 8.27 \mathrm{mmol}$ ) and tributylphosphine (Aldrich, $0.5 \mathrm{~mL}, 2.0 \mathrm{mmol}$ ) are added to the reaction mixture. $60-\mathrm{mL}$ aliquots are removed from the flask and placed in a CEM $80-\mathrm{mL}$ reaction vessel containing a stirbar. The reaction vessel is placed in the microwave cavity, sealed and heated at $140^{\circ} \mathrm{C}$ for $60 \mathrm{~min}$ at $300 \mathrm{~W}$ of power. This process is repeated until all of solution in the Erlenmeyer flask had been cycled through the microwave ( $\sim 2$ runs). The combined reaction mixtures are concentrated under reduced pressure and the resulting brown oil containing $\mathbf{2 1}$ is used without purification. Dilution of the crude reaction mixture in THF (50 $\mathrm{mL})$ followed by addition of $1 \mathrm{~N} \mathrm{HCl}(25 \mathrm{~mL}, 25 \mathrm{mmol})$ results in a reddish-orange solution. The acidic solution is stirred for an additional 30 min before removal of the volatile organics under reduced pressure. The resulting oil is diluted with water and basified by the addition of saturated aqueous $\mathrm{NaHCO}_{3}$ to raise the $\mathrm{pH}>8$. The basic solution is then extracted with $\mathrm{CH}_{2} \mathrm{Cl}_{2}(3 \times 75 \mathrm{~mL})$ and the combined organics are dried over $\mathrm{Na}_{2} \mathrm{SO}_{4}$. The drying agent is removed via filtration and the filtrate concentrated in vacuo. The resulting oil is purified by flash silica gel chromatography first eluting 1:1 EtOAc:hexanes to remove the benzophenone by-product then $95: 5 \mathrm{CH}_{2} \mathrm{Cl}_{2}: \mathrm{MeOH}$ to afford the amine $22(2.34 \mathrm{~g}, 90 \%)$ as a light yellow oil. ${ }^{1} \mathrm{H}$ NMR $\left(300 \mathrm{MHz}, \mathrm{CDCl}_{3}\right) \delta 1.24(\mathrm{t}, J=7.2 \mathrm{~Hz}, 3 \mathrm{H}), 1.44$ (s, 6H), 1.56 (br s. 2H), 2.97 (dd, $J=14.4,7.8 \mathrm{~Hz}, 1 \mathrm{H}), 3.23(\mathrm{dd}, J=4.1,0.6 \mathrm{~Hz}, 1 \mathrm{H}), 3.79$ (m, 1H), 4.15 $(\mathrm{q}, J=7.2 \mathrm{~Hz}, 2 \mathrm{H}), 5.64(\mathrm{~d}, J=9.9 \mathrm{~Hz}, 1 \mathrm{H}), 6.54(\mathrm{~d}, J=9.9 \mathrm{~Hz}, 1 \mathrm{H}), 6.67(\mathrm{~d}, J=8.7 \mathrm{~Hz}, 1 \mathrm{H}), 6.91(\mathrm{~d}$, $J=2.4 \mathrm{~Hz}, 1 \mathrm{H}), 7.33(\mathrm{~d}, J=8.7 \mathrm{~Hz}, 1 \mathrm{H}), 8.23$ (br. s, $1 \mathrm{H}) ;{ }^{13} \mathrm{C} \mathrm{NMR}\left(75 \mathrm{MHz}, \mathrm{CDCl}_{3}\right) \delta 176.19,152.91$, 132.88, 129.81, 121.99, 119.87, 117.55, 117.42, 114.13, 111.01, 105.01, 75.77, 64.21, 54.85, 35.44, 27.66 (2x), 15.10; HRMS-FAB: $[\mathrm{M}+\mathrm{H}]^{+}$calcd for $\mathrm{C}_{18} \mathrm{H}_{22} \mathrm{~N}_{2} \mathrm{O}_{3}, 315.1703$; found, 315.1719. 


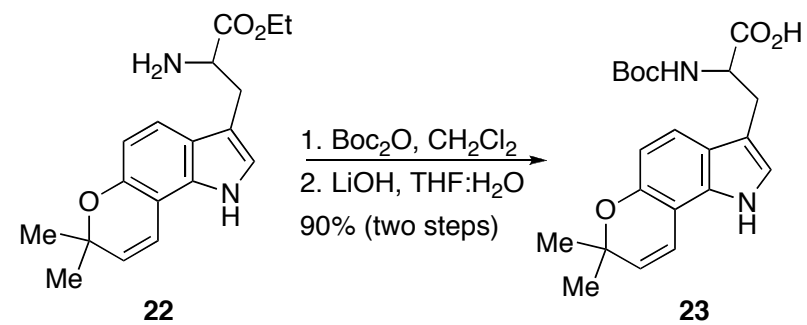

Carboxylic Acid 23. The amine $22(2.33 \mathrm{~g}, 7.44 \mathrm{mmol})$ is dissolved in $\mathrm{CH}_{2} \mathrm{Cl}_{2}(75 \mathrm{~mL})$ to give a homogenous solution at rt. Commercially available $\left(\mathrm{Boc}_{2}\right) \mathrm{O}(1.71 \mathrm{~g}, 8.20 \mathrm{mmol})$ is added followed by $0.5 \mathrm{~N} \mathrm{NaOH}(16 \mathrm{~mL})$. The reaction mixture is stirred until no more of the starting amine remained by TLC (95:5 $\mathrm{CH}_{2} \mathrm{Cl}_{2}: \mathrm{MeOH}, \sim 2 \mathrm{~h}$ ). The reaction mixture is then concentrated under reduced pressure and the resulting oil used without further purification.

The crude oil from the $N$-Boc protection is diluted with THF $(60 \mathrm{~mL})$ and water $(30 \mathrm{~mL})$. Commercially available LiOH (Aldrich, $1.56 \mathrm{~g}, 37.2 \mathrm{mmol}$ ) is added and the reaction mixture is stirred at $\mathrm{rt}$ for $4 \mathrm{~h}$. The volatile organics are then removed under reduced pressure and the resulting solid is suspended in water. $1 \mathrm{~N} \mathrm{KHSO}_{4}$ is slowly added to the rapidly stirred solution to lower the $\mathrm{pH}$ to $\sim 2$. The cloudy aqueous solution is extracted with EtOAc $(3 \times 75 \mathrm{~mL})$ and the combined extracts are dried over $\mathrm{Na}_{2} \mathrm{SO}_{4}$. The drying agent is removed via filtration and the filtrate is concentrated to afford the desired crude acid $23(2.57 \mathrm{~g}, 90 \%)$ as a foam, which was used without further purification. ${ }^{1} \mathrm{H} \mathrm{NMR}(300 \mathrm{MHz}$, $\left.\mathrm{CDCl}_{3}\right) 1.42(\mathrm{~s}, 9 \mathrm{H}), 1.46(\mathrm{~s}, 6 \mathrm{H}), 3.26(\mathrm{~m}, 2 \mathrm{H}), 4.61-4.65(\mathrm{~m}, 1 \mathrm{H}), 5.10(\mathrm{~d}, J=8.4 \mathrm{~Hz}, 1 \mathrm{H}), 5.63(\mathrm{~d}, J=$ $9.6 \mathrm{~Hz}, 1 \mathrm{H}), 6.57(\mathrm{~d}, J=9.6 \mathrm{~Hz}, 1 \mathrm{H}), 6.65(\mathrm{~d}, J=8.4 \mathrm{~Hz}, 1 \mathrm{H}), 6.80(\mathrm{~s}, 1 \mathrm{H}), 7.30(\mathrm{~d}, J=8.4 \mathrm{~Hz}, 1 \mathrm{H})$, 8.34 (br. s, 1H), 10.2-10.6 (br. s, $1 \mathrm{H}) ;{ }^{13} \mathrm{C} \mathrm{NMR} \mathrm{(75} \mathrm{MHz,} \mathrm{CDCl}_{3}$ ) $\delta 171.21,153.01,151.89,131.88$, $129.77,122.11,119.72,117.62,117.32,114.09,110.96,105.11,86.75,75.87,54.85,35.44,29.11(3 x)$, 27.66 (2x); HRMS-ESI; calcd for $\mathrm{C}_{21} \mathrm{H}_{26} \mathrm{~N}_{2} \mathrm{O}_{5}$, 387.1914; found, 387.1921.

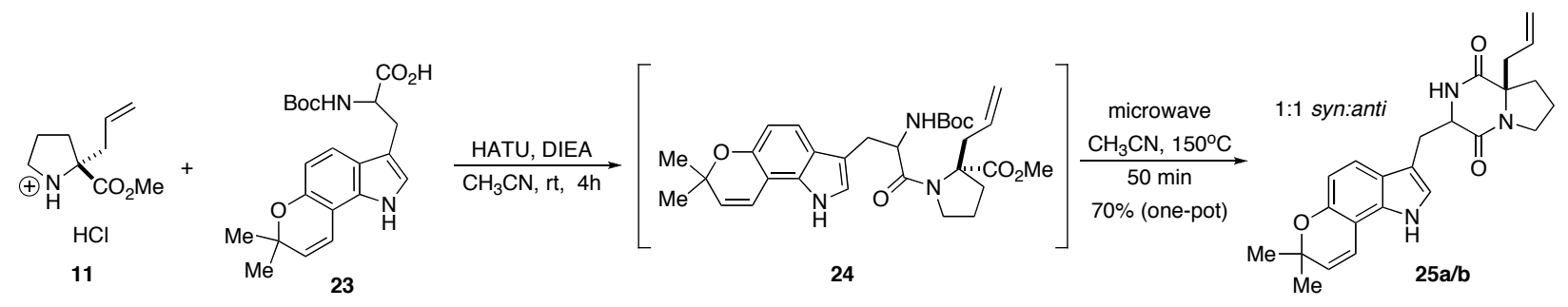

(3R,8aR,E)-8a-allyl-3-((7,7-dimethyl-1,7-dihydropyrano[2,3-g]indol-3-yl)methyl)hexahydropyrrolo[1,2-a]pyrazine-1,4-dione (25a) and (3S,8aR,E)-8a-allyl-3-((7,7-dimethyl-1,7dihydropyrano[2,3-g]indol-3-yl)methyl)-hexahydropyrrolo[1,2-a]pyrazine-1,4-dione (25b). To a $250-\mathrm{mL}$ round bottom flask, the amine salt $11(1.51 \mathrm{~g}, 7.33 \mathrm{mmol})$ and carboxylic acid 23 (2.57 g, 6.70 S-7 
mmol) were dissolved in $\mathrm{CH}_{3} \mathrm{CN}(120 \mathrm{~mL})$. Commercially available $N, N$-diisopropylethylamine (Aldrich, $3.00 \mathrm{~mL}, 16.8 \mathrm{mmol})$ and HATU (2.84 g, $7.40 \mathrm{mmol})$ were sequentially added. The reaction mixture was stirred at rt until no more of the starting amine was observed by TLC (95:5 EtOAc:hexanes for starting amine; 2:1 EtOAc:hexanes for amide product).

Once complete, the reaction mixture is divided into aliquots of $60 \mathrm{~mL}$. Each aliquot was placed into a $80-\mathrm{mL}$ reaction vessel for the CEM microwave reactor. Heating of the crude reaction mixture in the CEM microwave reactor at $150^{\circ} \mathrm{C}$ for $50 \mathrm{~min}$ at $300 \mathrm{~W}$ results in cleavage of the $N$-Boc protecting group and cyclization to afford crude $\mathbf{2 5} \mathbf{a} / \mathbf{b}$ based on TLC $\left(\right.$ EtOAc, 25a: $\left.\mathbf{R}_{f}=0.1 ; \mathbf{2 5} \mathbf{b}: \mathbf{R}_{f}=0.21\right)$. Once all the aliquots have been processed through the microwave reactor, the aliquots are combined and concentrated under reduced pressure. The resulting crude oil is diluted with EtOAc $(150 \mathrm{~mL})$ and washed sequentially with $1 \mathrm{~N} \mathrm{KHSO}_{4}(50 \mathrm{~mL})$, water $(50 \mathrm{~mL})$ and brine $(50 \mathrm{~mL})$. The organic solution is dried using $\mathrm{Na}_{2} \mathrm{SO}_{4}$, filtered to remove the insolubles and the filtrate is concentrated under reduced pressure. The resulting oil is purified via flash silica gel chromatography (EtOAc $\rightarrow$ 95:5 EtOAc: $\mathrm{MeOH})$ to afford first the anti diketopiperazine $\mathbf{2 5 b}(0.86 \mathrm{~g}, 32 \%)$ as a foam followed by the syn diketopiperazine 25a (1.03 g, 38\%) as a foam.

25a: ${ }^{1} \mathrm{H}$ NMR $\left(300 \mathrm{MHz}, \mathrm{CDCl}_{3}\right) \delta 1.46(\mathrm{~s}, 6 \mathrm{H}), 1.98-2.07(\mathrm{~m}, 3 \mathrm{H}), 2.18-2.29(\mathrm{~m}, 1 \mathrm{H}), 2.41-2.44(\mathrm{~m}$, $1 \mathrm{H}), 2.62-2.65(\mathrm{~m}, 1 \mathrm{H}), 2.93-2.99(\mathrm{~m}, 1 \mathrm{H}), 3.47-3.50(\mathrm{~m}, 2 \mathrm{H}), 4.08-4.15(\mathrm{~m}, 3 \mathrm{H}), 5.20-5.31(\mathrm{~m}, 2 \mathrm{H})$, 5.58-5.67 (m, 2H), $6.52(\mathrm{~d}, J=9.9 \mathrm{~Hz}, 1 \mathrm{H}), 6.64(\mathrm{~d}, J=8.4 \mathrm{~Hz}, 1 \mathrm{H}), 6.81$ (br. s, 1H), $7.32(\mathrm{~d}, J=8.4$ $\mathrm{Hz}, 1 \mathrm{H}), 7.82$ (br. s, $1 \mathrm{H}) ;{ }^{13} \mathrm{C}$ NMR $\left(75 \mathrm{MHz}, \mathrm{CDCl}_{3}\right.$ ) $\delta 172.31,170.42,151.92,149.24,137.92,133.31$, 128.61, 124.11, 124.01, 122.32, 120.17, 118.71, 113.93, 110.81, 75.97, 53.39, 52.44, 47.33, 35.87, 34.22, 29.99, 29.67, 26.4, 26.2; HRMS-FAB: [M+H] $]^{+}$calcd for $\mathrm{C}_{24} \mathrm{H}_{27} \mathrm{~N}_{3} \mathrm{O}_{3}$, 406.2125; found, 406.2131 . 25b: ${ }^{1} \mathrm{H}$ NMR $\left(300 \mathrm{MHz}, \mathrm{CDCl}_{3}\right) \delta 1.43$ (s, 3H), 1.44 (s, 3H), 1.80-2.20 (m, 2H), 2.44-2.65 (m, 2H), $2.85(\mathrm{dd}, J=15.0,10.8,1 \mathrm{H}), 3.48-3.65(\mathrm{~m}, 2 \mathrm{H}), 3.79-3.89(\mathrm{~m}, 1 \mathrm{H}), 4.03(\mathrm{~s}, 2 \mathrm{H}), 4.35(\mathrm{dd}, J=10.2,4.8$ $\mathrm{Hz}, 1 \mathrm{H}), 5.15-5.26$ (m, 2H), 5.45-5.60 (m, 2H), 5.89 (br. s, 1H), 6.57 (d, J=8.4 Hz, 1H), 6.63 (d, $J=8.4$ $\mathrm{Hz}, 1 \mathrm{H}), 6.99(\mathrm{~s}, 1 \mathrm{H}), 7.21(\mathrm{~d}, J=9.6 \mathrm{~Hz}, 1 \mathrm{H}), 8.90$ (br. s, 1H); HRMS-FAB: $[\mathrm{M}+\mathrm{H}]^{+}$calcd for $\mathrm{C}_{24} \mathrm{H}_{27} \mathrm{~N}_{3} \mathrm{O}_{3}$, 406.2125; found, 406.2130 . 

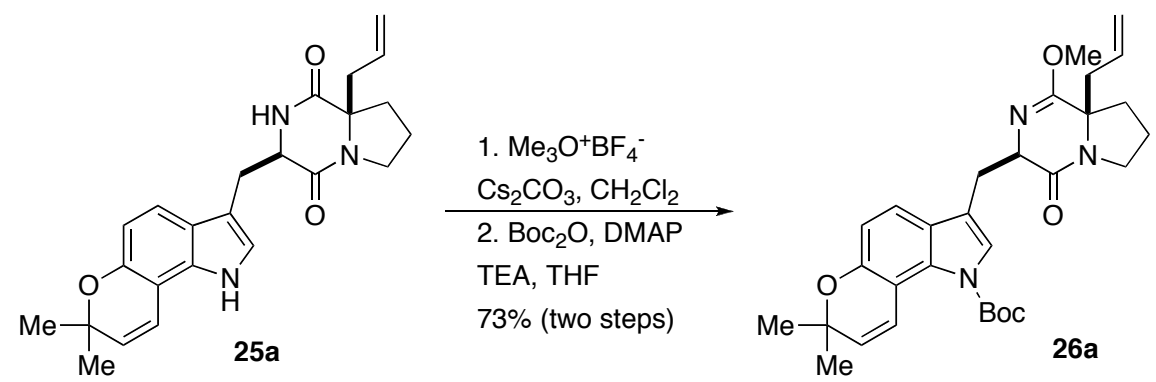

tert-Butyl 3-(((3R,8aR)-8a-allyl-1-methoxy-4-oxo-3,4,6,7,8,8a-hexahydropyrrolo[1,2-a]pyrazin-3yl)methyl)-7,7-dimethylpyrano[2,3-g]indole-1(7H)-carboxylate (26a). The DKP 25a (1.03 g, 3.00 $\mathrm{mmol})$ is dissolved in $\mathrm{CH}_{2} \mathrm{Cl}_{2}(60 \mathrm{~mL})$ and stirred at rt. Commercially available $\mathrm{Cs}_{2} \mathrm{CO}_{3}$ (Alfa Aesar, $14.6 \mathrm{~g}, 45 \mathrm{mmol})$ is added in a single portion. Commercially available $\mathrm{Me}_{3} \mathrm{O}^{+} \cdot \mathrm{BF}_{4}^{-}(2.22 \mathrm{~g}, 15 \mathrm{mmol})$ is ground into a fine powder and added to the reaction mixture in a single portion. The reaction continued stirring at $\mathrm{rt}$ until no more starting material remained by TLC (EtOAc, $\sim 6 \mathrm{~h}$ ). The reaction is poured into water $(50 \mathrm{~mL})$ and the organic layer removed. The aqueous solution is further extracted with $\mathrm{CH}_{2} \mathrm{Cl}_{2}(3$ x $40 \mathrm{~mL}$ ) and the combined organic extracts are dried over $\mathrm{Na}_{2} \mathrm{SO}_{4}$. The drying agent is removed by filtration through a sintered glass funnel and the volatile organics are removed in vacuo to afford an oil, which was used without further purification.

The crude lactim ether was dissolved in $\mathrm{CH}_{2} \mathrm{Cl}_{2}(30 \mathrm{~mL})$ and stirred at rt. Commercially available DMAP (Aldrich, $367 \mathrm{~g}, 3.00 \mathrm{mmol})$ and $\mathrm{Et}_{3} \mathrm{~N}(0.52 \mathrm{~mL}, 3.0 \mathrm{mmol})$ were added sequentially to the reaction mixture followed by commercially available $(\mathrm{Boc})_{2} \mathrm{O}(1.87 \mathrm{~g}, 9.00 \mathrm{mmol})$. The reaction mixture is stirred until no more of the unprotected indole was observed by TLC (2:1 EtOAc:hexanes, $2 \mathrm{~h})$. The reaction mixture is concentrated in vacuo and the crude reaction mixture is purified by flash silica gel chromatography (2:1 EtOAc:hexanes) to afford the desired protected compound 26a (1.12 g, $73 \%)$ as a foam. ${ }^{1} \mathrm{H}$ NMR $\left(300 \mathrm{MHz}, \mathrm{CDCl}_{3}\right) \delta 1.46(\mathrm{~s}, 6 \mathrm{H}), 1.59$ (s, 9H), 1.80-2.20 (m, 4H), 2.90 (dd, $J=14.4$, $9.3 \mathrm{~Hz}, 1 \mathrm{H}), 3.26-3.36$ (m, 2H), 3.65 (s, 3H), 3.91-3.94 (br. m, 2H), 3.98-4.04 (m, 1H), 4.34 (dd, $J=9.0$, $3.9 \mathrm{~Hz}, 1 \mathrm{H}), 5.15-5.21(\mathrm{~m} 2 \mathrm{H}), 5.45-5.57(\mathrm{~d}, J=9.9 \mathrm{~Hz}, 1 \mathrm{H}), 6.78(\mathrm{~d}, J=8.4 \mathrm{~Hz}, 1 \mathrm{H}), 6.98(\mathrm{~d}, J=9.9$ $\mathrm{Hz}, 1 \mathrm{H}), 7.32$ (d, $J=8.4 \mathrm{~Hz}, 1 \mathrm{H}), 7.39$ (s, 1H); HRMS-FAB: calcd for $\mathrm{C}_{30} \mathrm{H}_{37} \mathrm{~N}_{3} \mathrm{O}_{5}, 520.2806$; found, 520.2804 . 


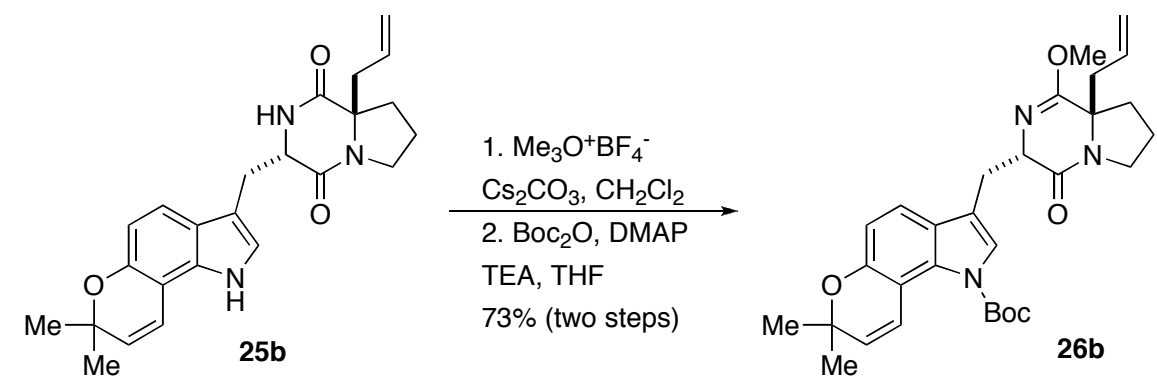

tert-Butyl

3-(((3S,8aR)-8a-allyl-1-methoxy-4-oxo-3,4,6,7,8,8a-hexahydropyrrolo[1,2a]pyrazin-3-yl)methyl)-7,7-dimethylpyrano[2,3-g]indole-1(7H)-carboxylate (26b). The procedure outlined for the conversion of $\mathbf{2 5 a}$ to $\mathbf{2 5} \mathbf{b}$ was followed using $\mathbf{2 5 b}$ (860 $\mathrm{mg}, 2.12 \mathrm{mmol}$ ) to afford $\mathbf{2 6 \mathbf { b }}$ (782 mg, $71 \%$ ), which was purified by flash silica gel chromatography (2:1 EtOAc:hexanes) to afford 26b as a foam. ${ }^{1} \mathrm{H}$ NMR $\left(300 \mathrm{MHz}, \mathrm{CDCl}_{3}\right) \delta 1.44$ (s, 3H), 1.46 (s, 3H), 1.59 (s, 9H), 1.70-2.00 (m, 3H), 2.25-2.40 (m, 3H), $3.09(\mathrm{dd}, J=14.4,6.9 \mathrm{~Hz}, 1 \mathrm{H}), 3.30-3.36(\mathrm{~m}, 2 \mathrm{H}), 3.62(\mathrm{~s}, 3 \mathrm{H}), 3.65-3.75(\mathrm{~m}, 1 \mathrm{H})$, $4.23(\mathrm{dd}, J=6.3,6.6 \mathrm{~Hz}, 1 \mathrm{H}), 5.20-5.27(\mathrm{~m}, 2 \mathrm{H}), 5.50-5.60(\mathrm{~m}, 2 \mathrm{H}), 6.76(\mathrm{~d}, J=8.4 \mathrm{~Hz}, 1 \mathrm{H}), 7.01(\mathrm{~d}, J$ $=9.9 \mathrm{~Hz}, 1 \mathrm{H}), 7.26(\mathrm{~s}, 1 \mathrm{H}), 7.40(\mathrm{~d}, J=8.4 \mathrm{~Hz}, 1 \mathrm{H})$; HRMS-FAB: calcd for $\mathrm{C}_{30} \mathrm{H}_{37} \mathrm{~N}_{3} \mathrm{O}_{5}, 520.2806$; found, 520.2811.
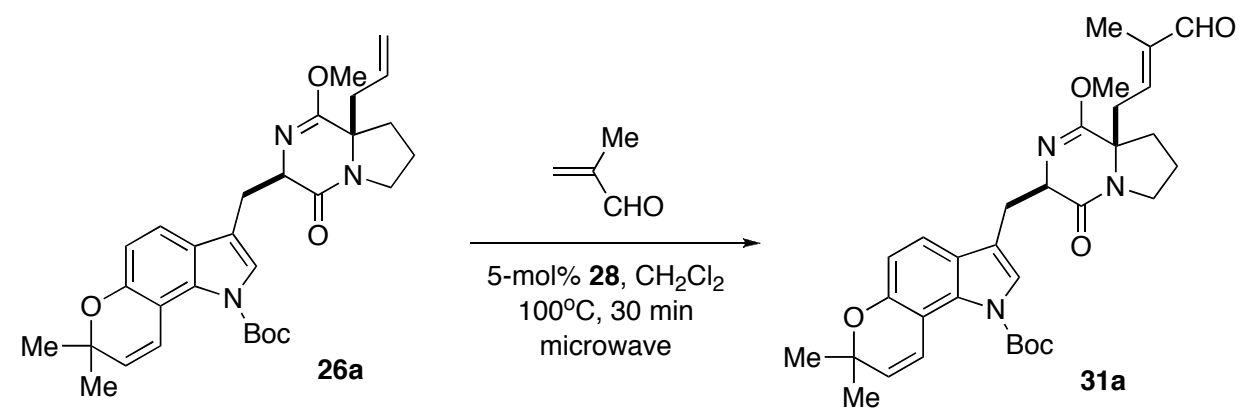

tert-Butyl

3-(((3R,8aR)-8a-((E)-4-carboxaldehyde-3-methylbut-2-enyl)-1-methoxy-4-oxo3,4,6,7,8,8a-hexahydropyrrolo[1,2-a]pyrazin-3-yl)methyl)-7,7-dimethylpyrano[2,3-g]indole-1(7H)carboxylate (31a). To a 25-mL round-bottomed flask, the allyl lactim ether $\mathbf{2 6 a}(250 \mathrm{mg}, 0.48 \mathrm{mmol})$ is dissolved in $\mathrm{CH}_{2} \mathrm{Cl}_{2}(5 \mathrm{~mL})$. Commercially available methacrolein (Aldrich, $0.5 \mathrm{~mL}, 6.0 \mathrm{mmol}$ ) is added in a single portion via syringe. The reaction mixture is stirred for $5 \mathrm{~min}$ then transferred to a CEM 10$\mathrm{mL}$ microwave tube. Commercially available Hoveyda-Grubbs $2^{\text {nd }}$ Generation catalyst (28, $15 \mathrm{mg}, 0.02$ mmol) is added to the microwave tube in a single portion. The microwave tube is capped and irradiated using a CEM Discovery unit for $30 \mathrm{~min}$ at $100^{\circ} \mathrm{C}$ at $200 \mathrm{~W}$ of power. Following cooling, the tube is removed and the contents are transferred to a $25-\mathrm{mL}$ round-bottomed flask and the volatile organics are S-10 
removed under reduced pressure. The remaining residue is purified by flash silica gel chromatography eluting 2:1 EtOAc:hexanes to afford the starting allyl 26a first (25 $\mathrm{mg}, 10 \%)$ followed by the desired aldehyde 31a (196 mg, 73\%) as an oil. ${ }^{1} \mathrm{H}$ NMR (300 MHz, $\left.\mathrm{CDCl}_{3}\right) \delta 1.46(\mathrm{~s}, 6 \mathrm{H}), 1.56(\mathrm{~s}, 3 \mathrm{H}), 1.59$ (s, 9H), 1.80-2.20 (m, 3H), 2.90 (dd, $J=14.4,9.3 \mathrm{~Hz}, 1 \mathrm{H}), 3.26-3.36$ (m, 2H), 3.65 (s, 3H), 3.91-3.94 (br. m, 2H), 3.98-4.04 (m, 1H), $4.34(\mathrm{dd}, J=9.0,3.9 \mathrm{~Hz}, 1 \mathrm{H}), 5.57(\mathrm{~d}, J=9.9 \mathrm{~Hz}, 1 \mathrm{H}), 6.42(\mathrm{t}, J=6.7 \mathrm{~Hz}$, $1 \mathrm{H}), 6.78(\mathrm{~d}, J=8.4 \mathrm{~Hz}, 1 \mathrm{H}), 6.98(\mathrm{~d}, J=9.9 \mathrm{~Hz}, 1 \mathrm{H}), 7.32(\mathrm{~d}, J=8.4 \mathrm{~Hz}, 1 \mathrm{H}), 7.39$ (s, 1H), 9.07 (s, 1H); HRMS-FAB: $[\mathrm{M}+\mathrm{H}]^{+}$calcd for $\mathrm{C}_{32} \mathrm{H}_{39} \mathrm{~N}_{3} \mathrm{O}_{6}, 562.2912$; found, 562.2911.

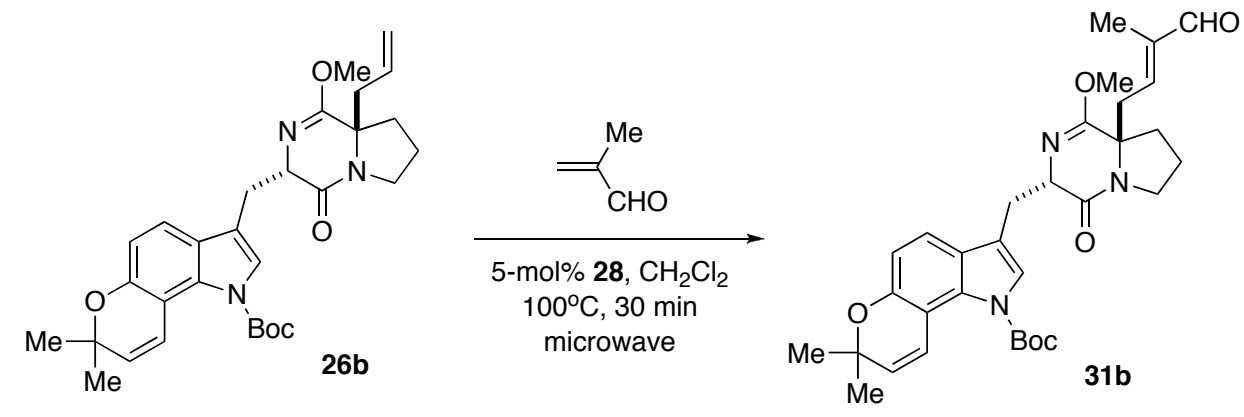

tert-Butyl

3-(((3S,8aR)-8a-((E)-4-carboxaldehyde-3-methylbut-2-enyl)-1-methoxy-4-oxo3,4,6,7,8,8a-hexahydropyrrolo[1,2-a]pyrazin-3-yl)methyl)-7,7-dimethylpyrano[2,3-g]indole-1(7H)carboxylate $(\mathbf{3 1 b})$. To a $25-\mathrm{mL}$ round-bottomed flask, the allyl lactim ether $\mathbf{2 6 \mathbf { b }}(250 \mathrm{mg}$, $\mathrm{mmol})$ is dissolved in $\mathrm{CH}_{2} \mathrm{Cl}_{2}(5 \mathrm{~mL})$. Commercially available methacrolein (Aldrich, $0.5 \mathrm{~mL}, 6.0 \mathrm{mmol}$ ) is added in a single portion via syringe. The reaction mixture is stirred for 5 min then transferred to a CEM 10mL microwave tube. Commercially available Hoveyda-Grubbs $2^{\text {nd }}$ Generation catalyst (28, $15 \mathrm{mg}, 0.02$ mmol) is added to the microwave tube in a single portion. The microwave tube is capped and irradiated using a CEM Discovery unit for $30 \mathrm{~min}$ at $100^{\circ} \mathrm{C}$ at $200 \mathrm{~W}$ of power. Following cooling, the tube is removed and the contents are transferred to a $25-\mathrm{mL}$ round-bottomed flask and the volatile organics are removed under reduced pressure. The remaining residue is purified by flash silica gel chromatography eluting 2:1 EtOAc:hexanes to afford the starting allyl 26b first (25 $\mathrm{mg}, 10 \%)$ followed by the desired aldehyde 31b (193 mg, $71 \%$ ) as an oil. ${ }^{1} \mathrm{H}$ NMR (300 MHz, $\left.\mathrm{CDCl}_{3}\right) \delta 1.44(\mathrm{~s}, 3 \mathrm{H}), 1.46(\mathrm{~s}, 3 \mathrm{H}), 1.57$ (s, $3 \mathrm{H}), 1.59$ (s, 9H), 1.70-2.00 (m, 3H), 2.25-2.40 (m, 3H), 3.09 (dd, $J=14.4,6.9 \mathrm{~Hz}, 1 \mathrm{H}), 3.30-3.36(\mathrm{~m}$, 2H), $3.62(\mathrm{~s}, 3 \mathrm{H}), 3.65-3.75(\mathrm{~m}, 1 \mathrm{H}), 3.92(\mathrm{~s}, 2 \mathrm{H}), 4.23(\mathrm{dd}, J=6.3,6.6 \mathrm{~Hz}, 1 \mathrm{H}), 5.27(\mathrm{t}, J=6.9 \mathrm{~Hz}$, $1 \mathrm{H}), 5.57(\mathrm{~d}, J=9.9 \mathrm{~Hz}, 1 \mathrm{H}), 6.31(\mathrm{t}, J=6.5 \mathrm{~Hz}, 1 \mathrm{H}) 6.76(\mathrm{~d}, J=8.4 \mathrm{~Hz}, 1 \mathrm{H}), 7.01(\mathrm{~d}, J=9.9 \mathrm{~Hz}, 1 \mathrm{H})$, $7.26(\mathrm{~s}, 1 \mathrm{H}), 7.40(\mathrm{~d}, J=8.4 \mathrm{~Hz}, 1 \mathrm{H}), 9.10(\mathrm{~s}, 1 \mathrm{H})$; HRMS-FAB: $[\mathrm{M}+\mathrm{H}]^{+}$calcd for $\mathrm{C}_{32} \mathrm{H}_{39} \mathrm{~N}_{3} \mathrm{O}_{6}$, 562.2912; found, 562.2917. 


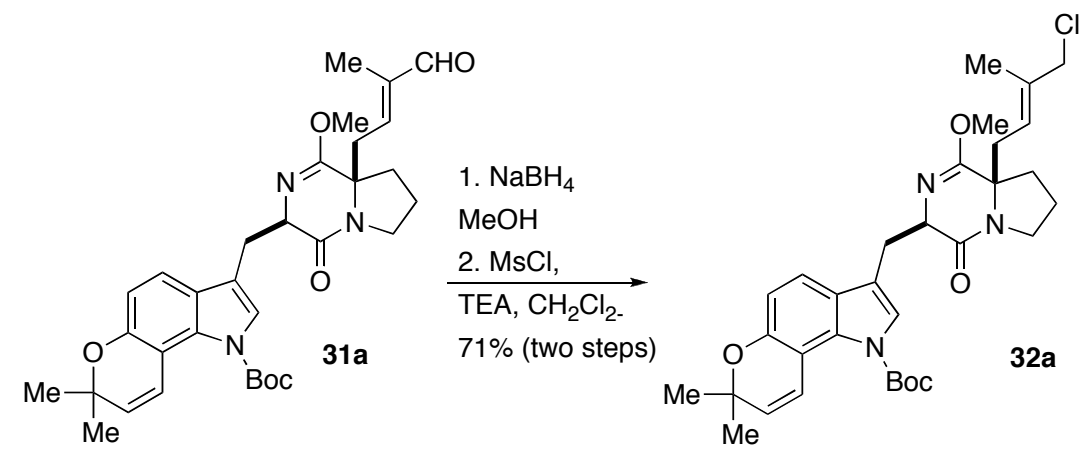

tert-butyl

3-(((3R,8aR)-8a-((E)-4-chloro-3-methylbut-2-enyl)-1,4dioxooctahydropyrrolo[1,2-a]pyrazin-3-yl)methyl)-7,7-dimethylpyrano[2,3-g]indole-1(7H)-

carboxylate (32a). To a $25-\mathrm{mL}$ round-bottomed flask, the aldehyde 31a (164 $\mathrm{mg}, 0.29 \mathrm{mmol})$ is dissolved in $\mathrm{MeOH}(5 \mathrm{~mL})$ then cooled in an ice/water bath. $\mathrm{NaBH}_{4}$ (Acros, $28 \mathrm{mg}, 0.90 \mathrm{mmol}$ ) is then added in a single portion and the reaction mixture is stirred at $0^{\circ} \mathrm{C}$ for an additional $5 \mathrm{~min}$. The cooling bath is then removed and the reaction is allowed to warm to rt. The reaction is monitored by TLC (3:1 EtOAc:hexanes) for the disappearance of the starting aldehyde $(\sim 1 \mathrm{~h})$. The reaction is quenched by the addition of aqueous saturated $\mathrm{NaHCO}_{3}(5 \mathrm{~mL})$. The aqueous solution is extracted with EtOAc $(3 \times 10$ $\mathrm{mL}$ ) and the combined organic extracts are dried over $\mathrm{Na}_{2} \mathrm{SO}_{4}$. Following removal of the drying agent, the filtrate is concentrated in vacuo and the resulting crude alcohol is used without further purification. ${ }^{1} \mathrm{H}$ NMR (300 MHz, $\left.\mathrm{CDCl}_{3}\right) \delta 1.46$ (s, 6H), 1.56 (s, 3H), 1.59 (s, 9H), 1.80-2.20 (m, 9H), 2.90 (dd, J= 14.4, $9.3 \mathrm{~Hz}, 1 \mathrm{H}), 3.26-3.36$ (m, 2H), 3.65 (s, 3H), 3.91-3.94 (br. m, 2H), 3.98-4.04 (m, 1H), 4.34 (dd, J $=9.0,3.9 \mathrm{~Hz}, 1 \mathrm{H}), 5.15(\mathrm{t}, J=7.5 \mathrm{~Hz}, 1 \mathrm{H}), 5.57(\mathrm{~d}, J=9.9 \mathrm{~Hz}, 1 \mathrm{H}), 6.78(\mathrm{~d}, J=8.4 \mathrm{~Hz}, 1 \mathrm{H}), 6.98(\mathrm{~d}, J$ $=9.9 \mathrm{~Hz}, 1 \mathrm{H}), 7.32(\mathrm{~d}, J=8.4 \mathrm{~Hz}, 1 \mathrm{H}), 7.39(\mathrm{~s}, 1 \mathrm{H})$.

To a $25-\mathrm{mL}$ round-bottomed flask, triethylamine $(100 \mu \mathrm{L}, 0.60 \mathrm{mmol})$ is added to the crude alcohol in $\mathrm{CH}_{2} \mathrm{Cl}_{2}(10 \mathrm{~mL})$. The reaction mixture is cooled in an ice/water bath for $10 \mathrm{~min}$ before the addition of commercially available methanesulfonyl chloride (Aldrich, $45 \mu \mathrm{L}, 0.60 \mathrm{mmol}$ ) via a syringe in a single portion. The reaction mixture is allowed to slowly warm to $\mathrm{rt}$ with stirring and is monitored by TLC (5:1 EtOAc:hexanes) for the disappearance of the starting alcohol $\left(\mathrm{R}_{f}=0.25, \sim 10 \mathrm{~h}\right)$. Once the reaction is finished, the volatile organics are removed and the resulting oil was purified by flash silica gel chromatography eluting 5:1 EtOAc:hexanes to afford the desired allyl chloride 32a (120 mg, 71\%) as an oil. ${ }^{1} \mathrm{H}$ NMR $\left(300 \mathrm{MHz}, \mathrm{CDCl}_{3}\right) \delta 1.34(\mathrm{~s}, 6 \mathrm{H}), 1.71(\mathrm{~s}, 9 \mathrm{H}), 1.75(\mathrm{~s}, 3 \mathrm{H}), 1.78-2.10(\mathrm{~m}, 4 \mathrm{H}), 2.22$ (m, 1H), $2.38(\mathrm{dd}, J=14.4,7.2 \mathrm{~Hz}, 1 \mathrm{H}), 2.61(\mathrm{dd}, J=14.4,8.4 \mathrm{~Hz}, 1 \mathrm{H}), 2.87(\mathrm{dd}, J=14.1,10.8 \mathrm{~Hz}$, $1 \mathrm{H}), 3.45-3.51(\mathrm{~m}, 2 \mathrm{H}), 4.06(\mathrm{~s}, 3 \mathrm{H}), 4.21(\mathrm{dt}, J=11.1,3.0 \mathrm{~Hz}, 1 \mathrm{H}), 5.2-5.58$ (br. t, $1 \mathrm{H}), 5.61(\mathrm{~d}, J=9.9$ $\mathrm{Hz}, 1 \mathrm{H}), 5.74$ (br. d, $J=3 \mathrm{~Hz}, 1 \mathrm{H}), 6.83$ (dd, $J=8.4,0.6 \mathrm{~Hz}, 1 \mathrm{H}), 6.99$ (dd, $J=9.9,0.6 \mathrm{~Hz}, 1 \mathrm{H}), 7.31$ S-12 
$(\mathrm{d}, J=8.4 \mathrm{~Hz}, 1 \mathrm{H}), 7.33(\mathrm{~s}, 1 \mathrm{H}) ;{ }^{13} \mathrm{C} \mathrm{NMR}\left(75 \mathrm{MHz}, \mathrm{CDCl}_{3}\right) \delta 173.99,167.65,156.88,152.45,148.91$, 137.62, 132.91, 127.04, 124.62, 123.87, 122.01, 120.54, 119.76, 113.39, 111.32, 86.01, 75.67, 61.01, $58.17,57.97,51.21,41.55,37.11,34.01,28.67$ (3x), 28.56, 27.7, 27.3, 24.5, 19.21; HRMS-FAB: $[\mathrm{M}+\mathrm{H}]^{+}$calcd for $\mathrm{C}_{32} \mathrm{H}_{40} \mathrm{~N}_{3} \mathrm{O}_{5} \mathrm{Cl}, 582.2729$; found, 582.2731 .
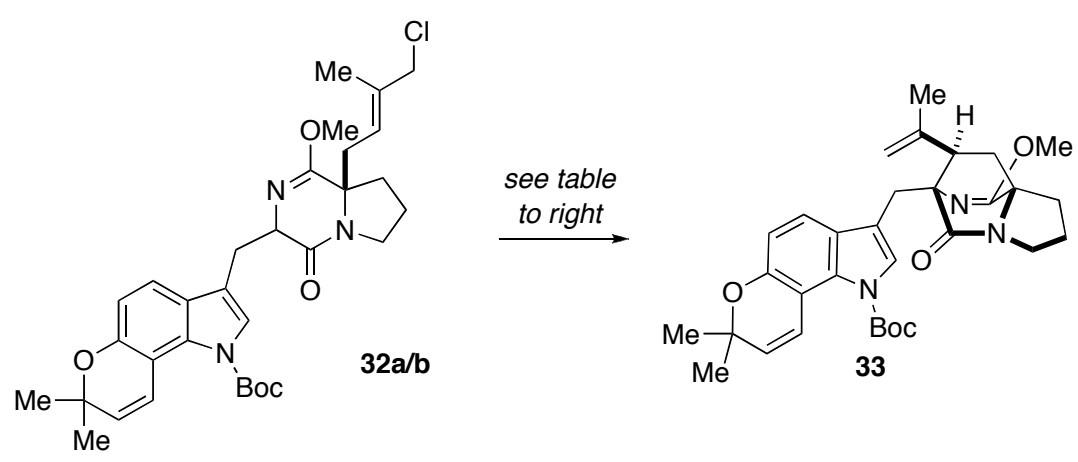

\begin{tabular}{cc}
$\begin{array}{cc}\text { Conditions } \\
\text { NaH, THF }\end{array}$ & Results \\
reflux, 30h & $60 \%$ \\
NaH, PhH & \\
microwave & $63 \%$ \\
$120^{\circ} \mathrm{C}, 30$ min & \\
NaH, PhH & $71 \%+$ \\
sealed tube & $10 \% \mathrm{SM}$ \\
$130^{\circ} \mathrm{C}, 9 \mathrm{~h}$ & \\
\hline
\end{tabular}

$\mathbf{S}_{\mathrm{N}} \mathbf{2}^{\prime}$ Cyclization of 32a/b (33). To a 25-mL round-bottomed flask, the allyl chloride 32a/b (100 mg, $0.17 \mathrm{mmol})$ is dissolved in $\mathrm{PhH}(10 \mathrm{~mL})$ and transferred to a 42-mL sealed tube. Commercially available $\mathrm{NaH}(60 \%$ dispersion, Aldrich, $140 \mathrm{mg}, 3.5 \mathrm{mmol})$ is suspended in petroleum ether $(5 \mathrm{~mL})$ and stirred at rt for $20 \mathrm{~min}$. The cloudy solution is filtered through a sinter glass funnel and the remaining $\mathrm{NaH}$ is added to the sealed tube. The reaction vessel is tightly sealed and placed in an oil bath and heated to $130^{\circ} \mathrm{C}$ for $9 \mathrm{~h}$. The progress of the reaction is occasionally monitored by TLC (5:1 EtOAc:hexanes) for the disappearance of the starting allyl chloride 32a. Once the reaction is complete, the reaction is cooled to $0^{\circ} \mathrm{C}$ in an ice/water bath and slowly quenched by the addition of water $(1 \mathrm{~mL})$. Once no more $\mathrm{NaH}$ is visibly suspended in solution, the reaction mixture is poured into an additional quantity of water $(8 \mathrm{~mL})$ and the organic layer is separated. The aqueous layer is extracted with EtOAc $(3 \times 10 \mathrm{ml})$ and the combined organic extracts are dried over $\mathrm{Na}_{2} \mathrm{SO}_{4}$, filtered to remove the drying agent and concentrated under reduced pressure. The crude product is purified by flash silica gel chromatography eluting 2:1 EtOAc:hexanes to afford the bridged bicycle $33(65 \mathrm{mg}, 71 \%)$ as an oil in addition to recovered $32 \mathbf{a}$ (10 $\mathrm{mg}, 10 \%)$.

The same procedure detailed above was employed for allyl chloride $\mathbf{3 2} \mathbf{b}$ and afforded the desired bridged bicycle 33 in $70 \%$ yield in addition to recovered $32 b(8 \mathrm{mg}, 8 \%) .{ }^{1} \mathrm{H} \mathrm{NMR}\left(500 \mathrm{MHz}, \mathrm{CDCl}_{3}\right) \delta$ $1.49(\mathrm{~s}, 3 \mathrm{H}), 1.50(\mathrm{~s}, 3 \mathrm{H}), 1.63(\mathrm{~s}, 9 \mathrm{H}), 1.69(\mathrm{~s}, 3 \mathrm{H}), 1.82-1.88(\mathrm{~m}, 1 \mathrm{H}), 1.91-1.99(\mathrm{~m}, 2 \mathrm{H}), 2.02-2.07$ $(\mathrm{m}, 1 \mathrm{H}), 2.52(\mathrm{dd}, J=10.5,5.5 \mathrm{~Hz}, 1 \mathrm{H}), 2.60(\mathrm{dt}, J=12.5,5.5 \mathrm{~Hz}, 1 \mathrm{H}), 3.11(\mathrm{~d}, J=15.0 \mathrm{~Hz}, 1 \mathrm{H}), 3.40$ S-13 
$(\mathrm{d}, J=15.0 \mathrm{~Hz}, 1 \mathrm{H}), 3.44-3.48(\mathrm{~m}, 1 \mathrm{H}), 3.55-3.60(\mathrm{~m}, 1 \mathrm{H}), 3.68(\mathrm{~s}, 3 \mathrm{H}), 4.76(\mathrm{~s}, 1 \mathrm{H}), 4.88(\mathrm{~s}, 1 \mathrm{H}), 5.60$ $(\mathrm{d}, J=10.0 \mathrm{~Hz}, 1 \mathrm{H}), 6.78(\mathrm{~d}, J=8.5 \mathrm{~Hz}, 1 \mathrm{H}), 7.07(\mathrm{~d}, J=10.0 \mathrm{~Hz}, 1 \mathrm{H}), 7.54(\mathrm{~s}, 1 \mathrm{H}), 7.61(\mathrm{~d}, J=8.5$ $\mathrm{Hz}, 1 \mathrm{H}) ;{ }^{13} \mathrm{C} \mathrm{NMR}\left(125 \mathrm{MHz}, \mathrm{CDCl}_{3}\right) \delta 172.1,171.8,151.3,150.4,144.4,132.0,127.9,126.8,126.4$, 122.3, 122.1, 117.2, 115.4, 112.9, 109.5, 83.1, 74.9, 69.3, 64.1, 54.7, 48.7, 43.6, 37.8, 29.2, 28.4, 27.5, 27.3, 27.0, 25.0, 19.7. HRMS-FAB: $[\mathrm{M}+\mathrm{H}]^{+}$calcd for $\mathrm{C}_{32} \mathrm{H}_{39} \mathrm{~N}_{3} \mathrm{O}_{5}, 546.2962$; found, 546.2961.
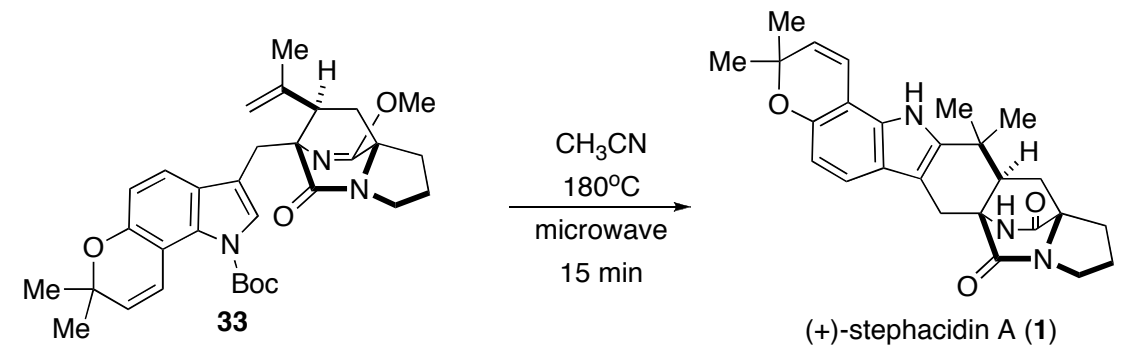

(-)-Stephacidin A (1). To a 10-mL round-bottomed flask, the bridged bicycle 33 (15 mg, 0.027 mmol) is dissolved in $\mathrm{CH}_{3} \mathrm{CN}(1 \mathrm{~mL})$. Commercially available $\mathrm{Pd}(\mathrm{TFA})_{2}(50 \mathrm{mg}, 0.15 \mathrm{mmol})$ is added in a single portion and the reaction mixture is stirred at $\mathrm{rt}$ and monitored by TLC (2:1 EtOAc:hexanes) for the consumption of the starting olefin 33 ( 30 min). Once no more of the starting olefin is visible by TLC, the reaction mixture is diluted with $\mathrm{EtOH}(1 \mathrm{~mL})$ and cooled to $0^{\circ} \mathrm{C}$ in an ice/water bath. $\mathrm{NaBH}_{4}$ (Acros, $10 \mathrm{mg}, 0.33 \mathrm{mmol}$ ) is added slowly over $10 \mathrm{~min}$ to quench the intermediate alkyl-palladium species during which excessive gas evolution is observed and palladium crashes out of solution as Pd black. The reaction is stirred for an additional $30 \mathrm{~min}$ before concentration in vacuo. The crude product is dissolved in EtOAc ( $5 \mathrm{~mL})$ and filtered through a plug of Celite ${ }^{\circledR}$ to remove any residual Pd black. The filtrate is washed with $0.1 \mathrm{~N} \mathrm{HCl}(2 \times 2.5 \mathrm{~mL})$ and the combined aqueous extracts are back extracted with EtOAc $(2 \times 5 \mathrm{~mL})$. The combined organic extracts are dried over $\mathrm{Na}_{2} \mathrm{SO}_{4}$ and the volatile organics are removed under reduced pressure. The crude heptacycle is dissolved in $\mathrm{CH}_{3} \mathrm{CN}(1 \mathrm{~mL})$ and heated in a $10-\mathrm{mL}$ CEM microwave tube at $180^{\circ} \mathrm{C}$ for $15 \mathrm{~min}$. The volatile organics are removed under reduced pressure to afford (-)-stephacidin A $(1,7 \mathrm{mg}, 58 \%)$ as white flaky powder that displayed spectral $\left({ }^{1} \mathrm{H}\right.$ NMR and HRMS) and physical properties to those reported in the literature. ${ }^{1} \mathrm{H}$ NMR $(400 \mathrm{MHz}$, DMSO) $\delta 0.96$ (s, 3H), 1.19 (s, 3H), 1.25 (s, 3H), 1.33 (s 3H), 1.77-1.87 (m, 2H), 1.90-1.99 (m, 2H), $2.01(\mathrm{dd}, J=13.9,10.1 \mathrm{~Hz}, 1 \mathrm{H}), 2.39(\mathrm{dd}, J=9.8,5.0 \mathrm{~Hz}, 1 \mathrm{H}), 2.48$ (m, 1H, underneath DMSO peak), $2.59(\mathrm{~d}, J=15.5 \mathrm{~Hz}, 1 \mathrm{H}), 3.20-3.29(\mathrm{~m}, 3 \mathrm{H}), 5.65(\mathrm{~d}, J=9.8 \mathrm{~Hz}, 1 \mathrm{H}), 6.43(\mathrm{~d}, J=8.3 \mathrm{~Hz}, 1 \mathrm{H}), 6.87$ (d, $J=9.8 \mathrm{~Hz}, 1 \mathrm{H}), 7.02(\mathrm{~d}, J=8.3 \mathrm{~Hz}, 1 \mathrm{H}), 8.62(\mathrm{~s}, 1 \mathrm{H}), 10.39(\mathrm{~s}, 1 \mathrm{H})$; HRMS-FAB: $[\mathrm{M}+\mathrm{H}]^{+}$calcd for $\mathrm{C}_{26} \mathrm{H}_{29} \mathrm{~N}_{3} \mathrm{O}_{3}$, 432.2287; found, 432.2282. 
Published ${ }^{1}$ H NMR Spectra of Stephacidin A by the Baran Group in $\mathrm{d}_{6}-\mathrm{DMSO}^{2}$

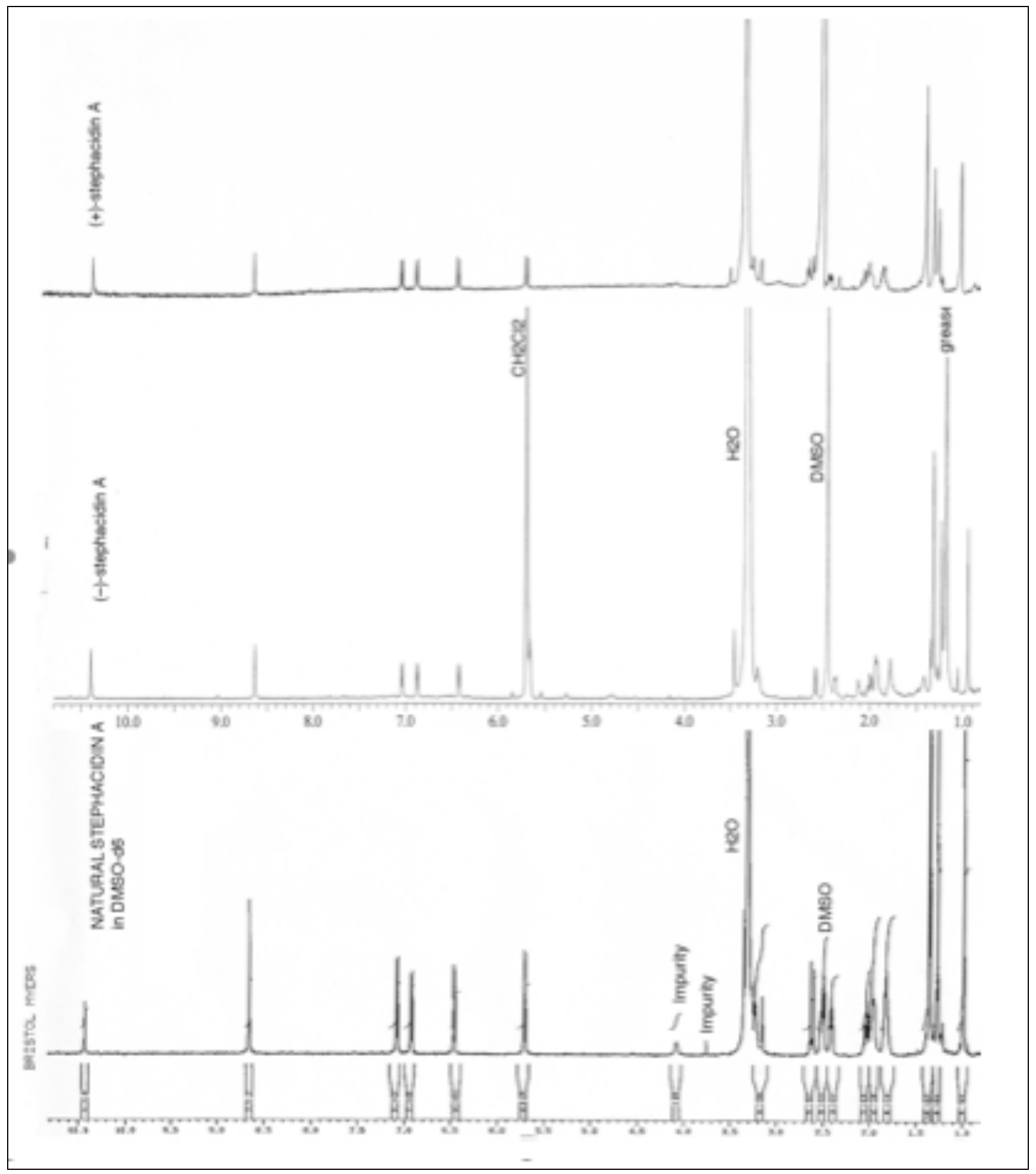

${ }^{2}$ Baran, P. S.; Hafensteiner, B. D.; Ambhaikar, N. B.; Guerrero, C. A.; Gallagher, J. D. J. Am. Chem. Soc. 2006, 128, 8678-8693.

S-15 
${ }^{1} \mathrm{H}$ NMR of synthetic (-)-Stephacidin A (400 MHz, $\left.\mathrm{d}_{6}-\mathrm{DMSO}\right)$

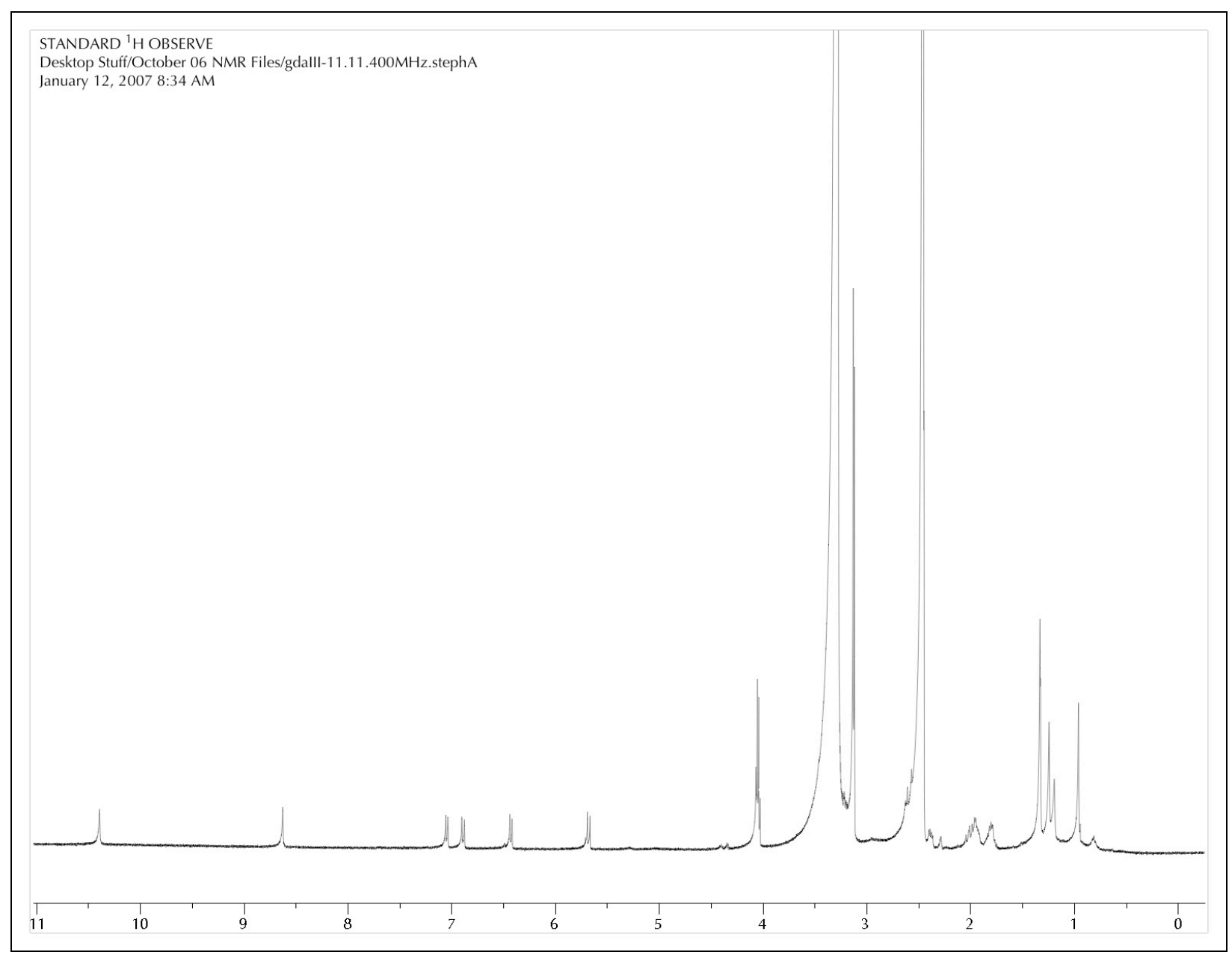



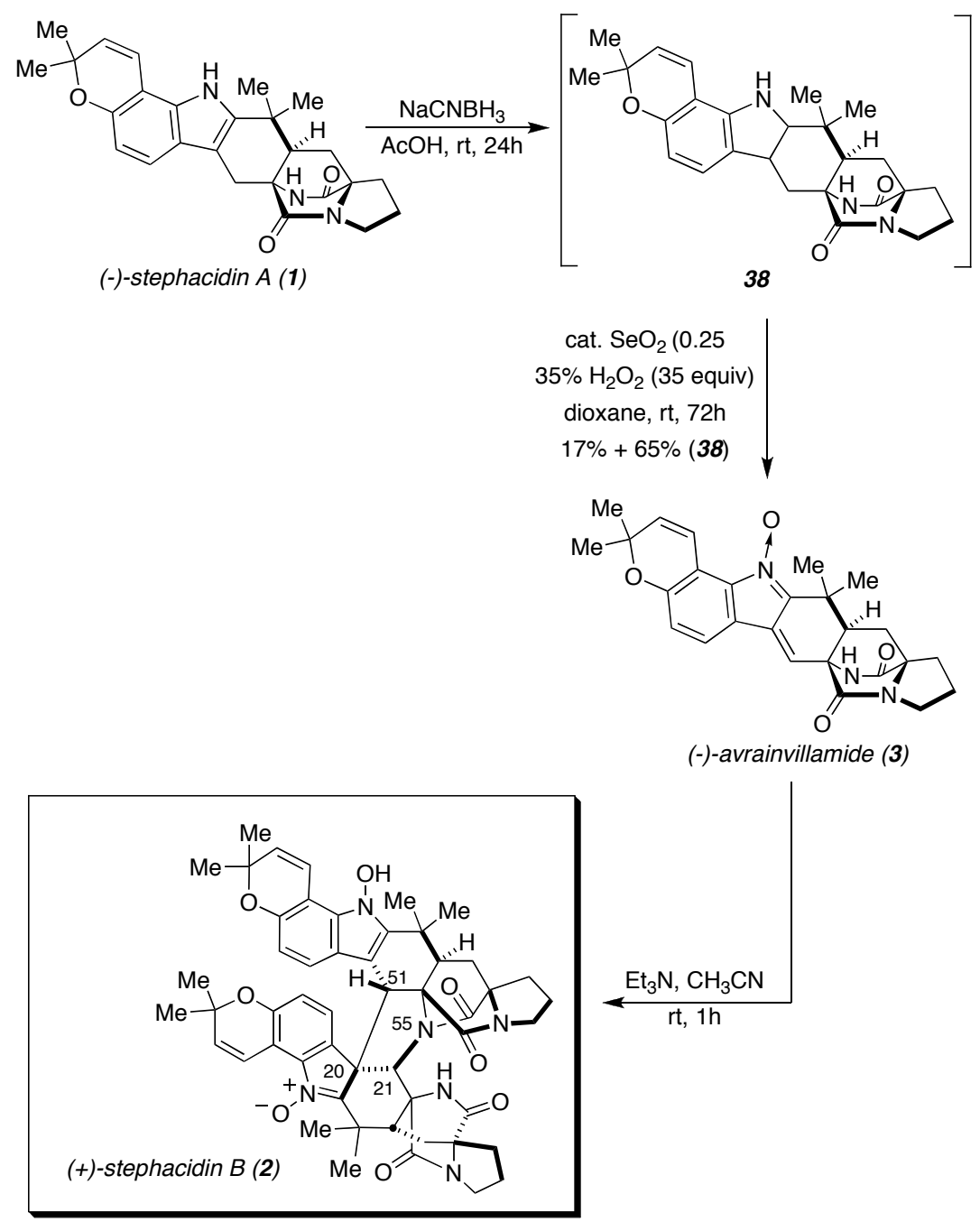

(+)-Stephacidin B (2). The previously reported procedure developed by Baran for the oxidation of stephacidin A (1) to avrainvillamide (3) was followed using $7 \mathrm{mg}$ of $\mathbf{1}$ to afford $1 \mathrm{mg}$ of $\mathbf{3}$ (17\%). The totally synthetic avrainvillamide (3) was dimerized to (+)-stephacidin B (2) using the procedure developed by Myers' laboratory in $~ 100 \%$ yield by NMR analysis.

Spectral Data for (+)-Stephacidin B (2): ${ }^{1} \mathrm{H}$ NMR (400 MHz, CD ${ }_{3} \mathrm{CN}$ :DMSO 1:1) $\delta 1.01$ (s, $3 \mathrm{H}$ ), 1.14 (s, 3H), 1.23 (s, 3H), 1.27-1.32 (br. s, 6H), 1.37 (s, 3H), 1.55 (s, 3H), 1.68 (s, 3H), 1.91-1.76 (m, 4H), 2.00-2.15 (br. m, 4H), 2.28 (m, 1H), 2.52 (br. m, 2H), 2.71 (br. m, 1H), 2.77 (br. m, 1H), 3.15-3.24 (br. m, 2H), 3.34-3.44 (br. m, 2H), 3.46-3.49 (m, 1H), 4.90 (s, 1H), $5.31(\mathrm{~s}, 1 \mathrm{H}), 5.57$ (d, J = 10.1 Hz, 1H), $5.62(\mathrm{~d}, J=10.3 \mathrm{~Hz}, 1 \mathrm{H}), 6.38(\mathrm{~d}, J=9.3 \mathrm{~Hz}, 1 \mathrm{H}), 6.51(\mathrm{~d}, J=8.3 \mathrm{~Hz}, 1 \mathrm{H}), 7.00(\mathrm{~d}, J=10.6 \mathrm{~Hz}, 1 \mathrm{H})$, $7.08(\mathrm{~d}, J=10.5 \mathrm{~Hz}, 1 \mathrm{H}), 7.44(\mathrm{~d}, J=9.2 \mathrm{~Hz}, 1 \mathrm{H}), 7.47$ (d, $J=9.2 \mathrm{~Hz}, 1 \mathrm{H}), 7.74(\mathrm{~s}, 1 \mathrm{H}), 10.72(\mathrm{~s}, 1 \mathrm{H})$; HRMS-FAB: $[\mathrm{M}+\mathrm{H}]^{+}$calcd for $\mathrm{C}_{52} \mathrm{H}_{54} \mathrm{~N}_{6} \mathrm{O}_{8}, 891.4076$; found, 891.4071. 
Published ${ }^{1} \mathrm{H}$ NMR Spectra of Stephacidin B by the Baran Group in $\mathrm{d}_{6}-\mathrm{DMSO}: \mathrm{CD}_{3} \mathrm{CN}^{2}$

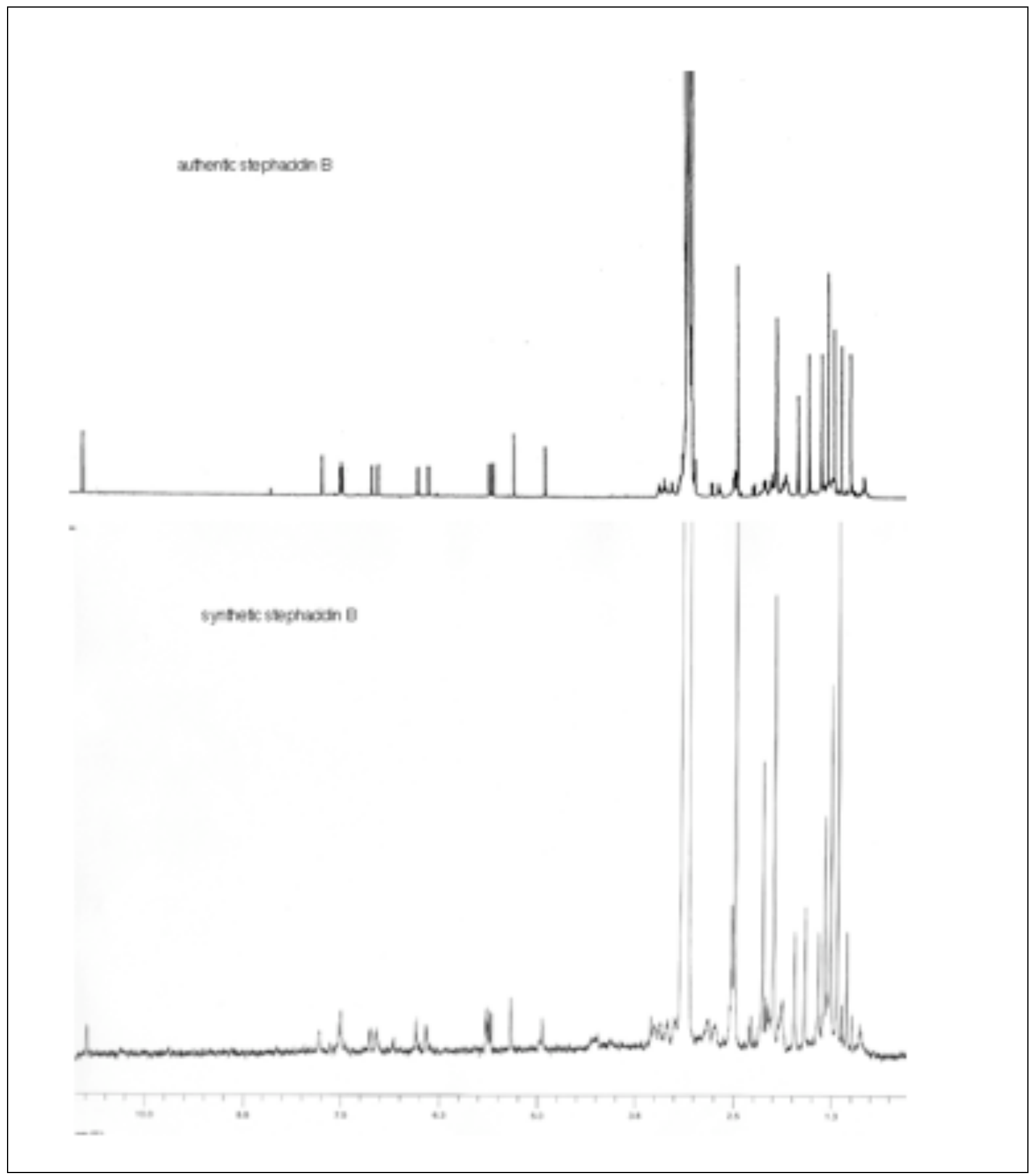


${ }^{1} \mathrm{H}$ NMR Spectrum of synthetic (+)-Stephacidin B (400 MHz, $\left.\mathrm{d}_{6}-\mathrm{DMSO}: \mathrm{CD}_{3} \mathrm{CN}\right)$

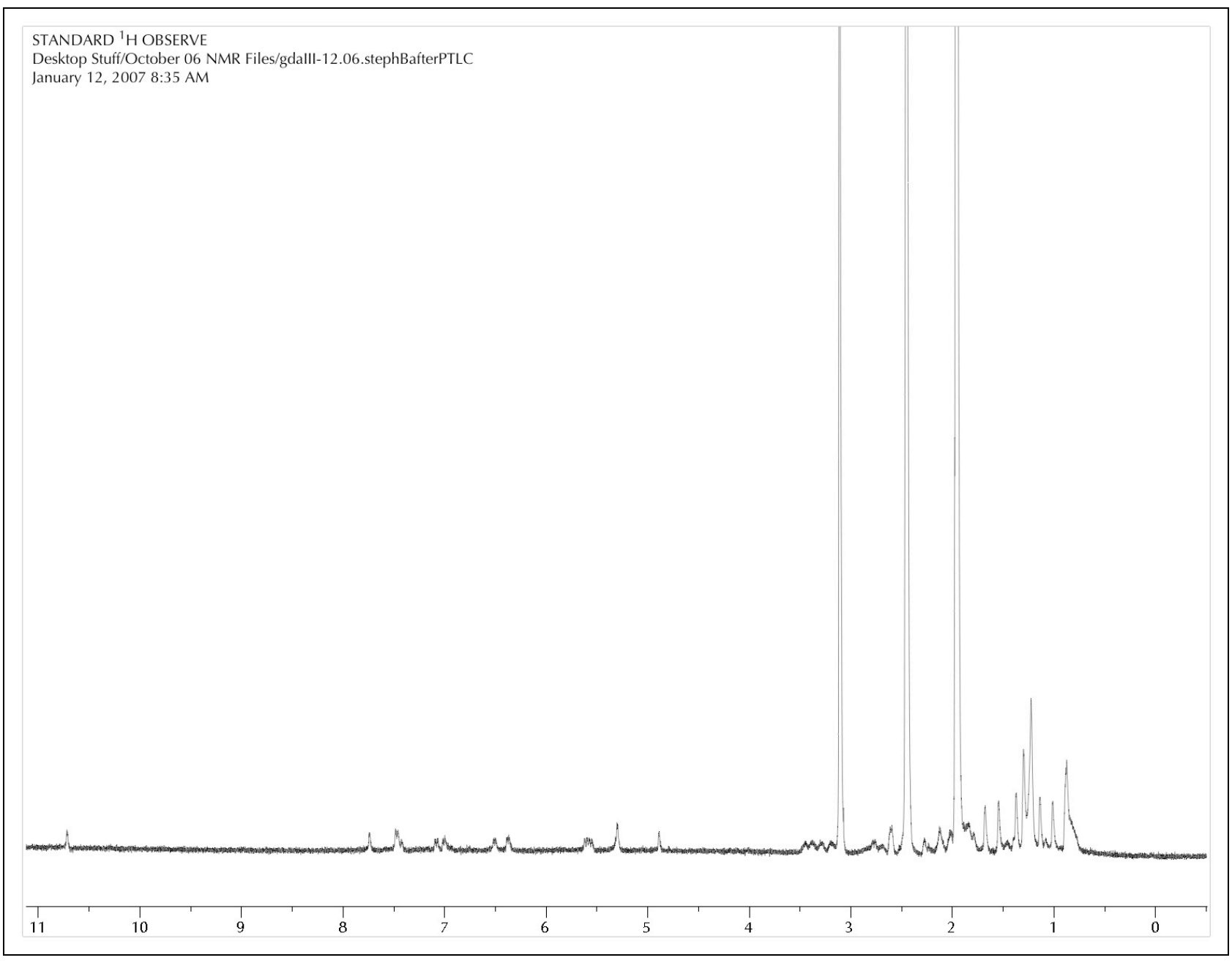

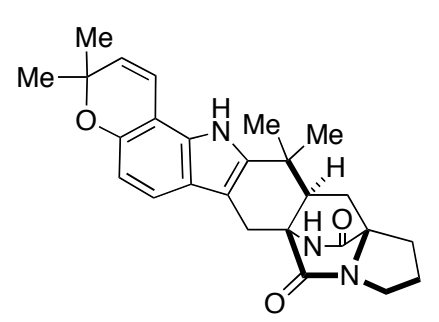

(+)-stephacidin A (1)

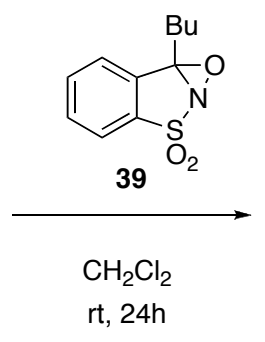

$65 \%$

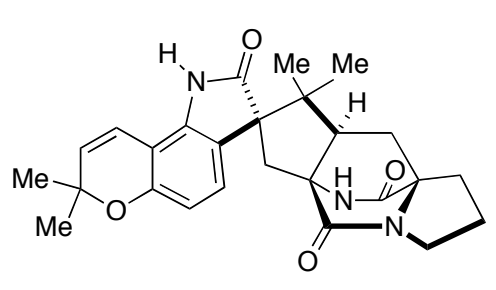

(+)-notoamide B (4)

(+)-Notoamide B (4). To a 5-mL round bottomed flask, (+)-Stephacidin A (1, $3 \mathrm{mg}, 0.007 \mathrm{mmol})$ was suspended in $\mathrm{CH}_{2} \mathrm{Cl}_{2}(1 \mathrm{~mL})$. The oxaziridine $39(30 \mathrm{mg}, 0.125 \mathrm{mmol})$ was added in a single portion and the reaction mixture was stirred at $\mathrm{rt}$ for $24 \mathrm{~h}$ during, which time the solution slowly becomes clear. The S-19 
reaction is then quenched by the addition of saturated aqueous $\mathrm{Na}_{2} \mathrm{~S}_{2} \mathrm{O}_{3}(2 \mathrm{~mL})$ and the organic layer is separated from the aqueous. The aqueous layer is extracted twice more with $\mathrm{CH}_{2} \mathrm{Cl}_{2}(2 \times 2 \mathrm{~mL})$ and the combined extracts are dried over $\mathrm{Na}_{2} \mathrm{SO}_{4}$. Removal of the drying agent and the volatile organics under reduced pressure gives the crude product, which is purified by PTLC eluting 95:5 $\mathrm{CH}_{2} \mathrm{Cl}_{2}: \mathrm{MeOH}$ to afford (+)-notoamide B (2 mg, 65\%). The product displayed good spectral correlation to the reported data, but with opposite sign of rotation: $[\alpha]_{\mathrm{D}}=+114^{\circ}(c 0.05, \mathrm{MeOH})$; lit: $[\alpha]_{\mathrm{D}}=-118^{\circ}(c 0.064$,

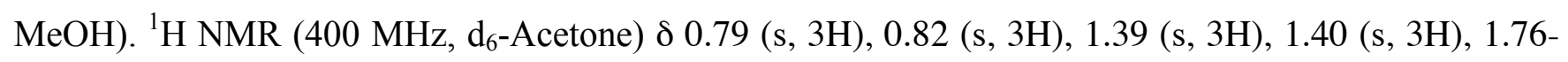
$2.06(\mathrm{~m}, 5 \mathrm{H}$, underneath acetone peak), $2.23(\mathrm{~d}, J=14.1 \mathrm{~Hz}, 1 \mathrm{H}), 2.60-2.67(\mathrm{~m}, 1$, underneath water peak), $3.02(\mathrm{~d}, J=14.2 \mathrm{~Hz}, 1 \mathrm{H}), 3.37(\mathrm{dd}, J=10.1,8.4 \mathrm{~Hz}, 1 \mathrm{H}), 3.40-3.59(\mathrm{~m}, 2 \mathrm{H}), 5.78(\mathrm{~d}, J=9.5 \mathrm{~Hz}$, $1 \mathrm{H}), 6.39$ (d, $J=8.5 \mathrm{~Hz}, 1 \mathrm{H}), 6.63(\mathrm{~d}, J=9.5 \mathrm{~Hz}, 1 \mathrm{H}), 7.07$ (d, $J=8.5 \mathrm{~Hz}, 1 \mathrm{H}), 8.00$ (br. s, $1 \mathrm{H}), 9.45$ (br. s, 1H); HRMS-FAB: $[\mathrm{M}+\mathrm{H}]^{+}$calcd for $\mathrm{C}_{26} \mathrm{H}_{29} \mathrm{~N}_{3} \mathrm{O}_{4}, 448.2231$; found, 448.2237 .

\section{Published ${ }^{1} \mathrm{H}$ NMR Spectrum of Notoamide B by the Tsukamoto Group in $\mathrm{d}_{6}$-Acetone ${ }^{3}$}

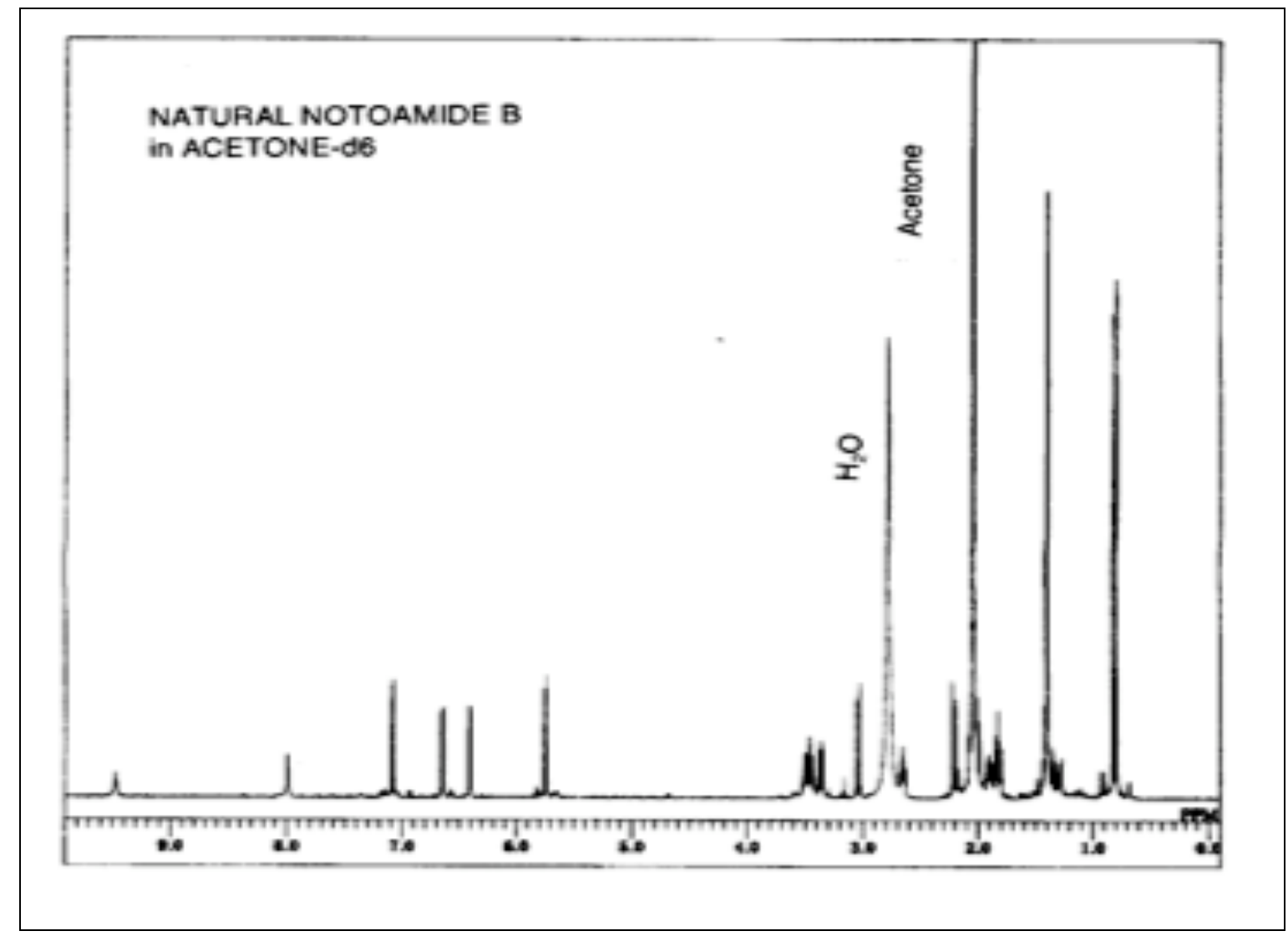

${ }^{3}$ Kato, H.; Yoshida, T.; Tokue, T.; Nojiri, Y.; Hirota, H.; Ohta, T.; Williams, R. M.; Tsukamoto, S. Angew. Chem. Int. Ed. 2006, 46, 2254-2256. 
${ }^{1} \mathrm{H}$ NMR Spectrum of synthetic (+)-Notoamide $B$ in $d_{6}$-Acetone

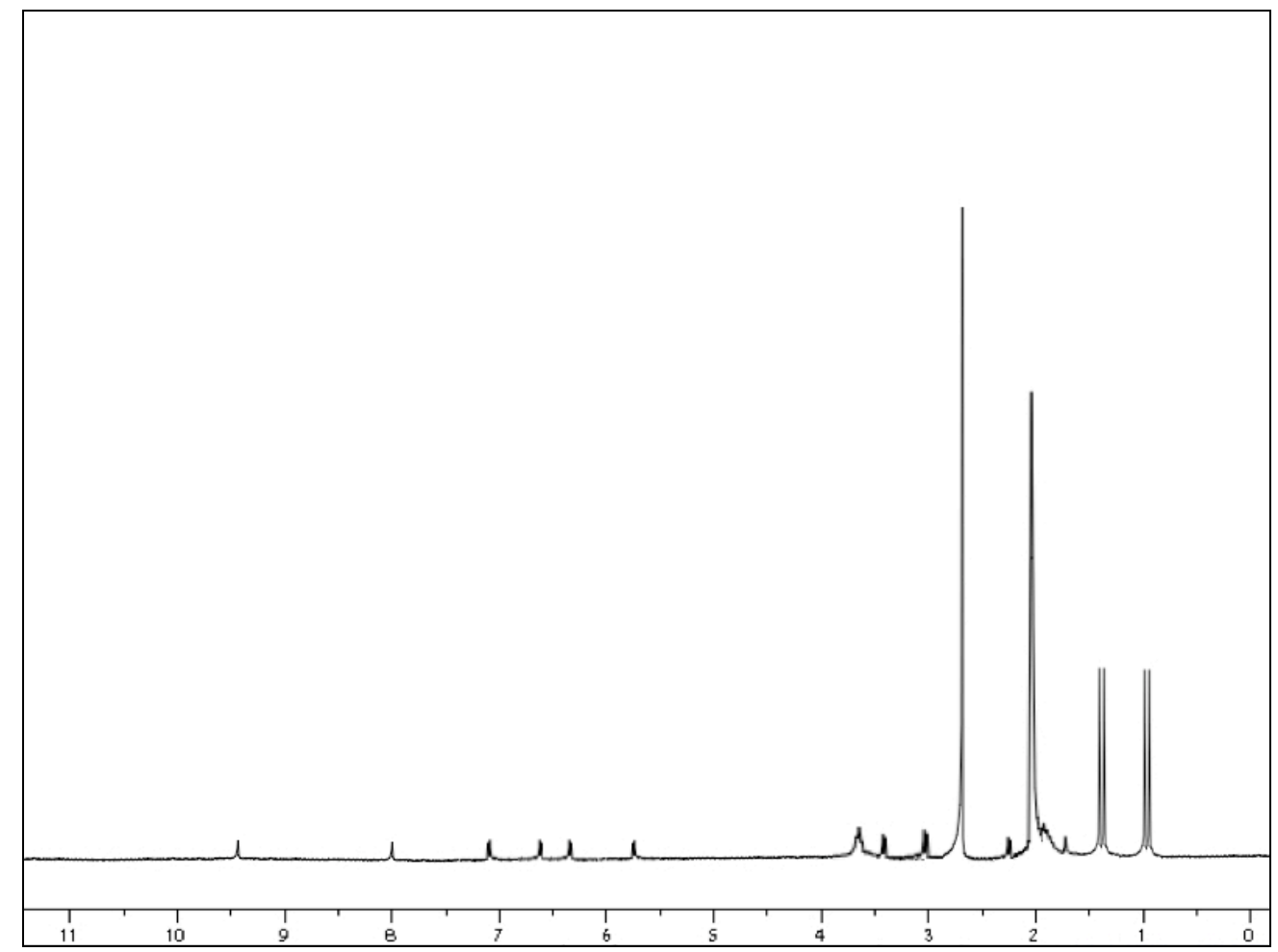

